\author{
DOMINIK KANIGOWSKI, JOANNA URBAN-CIEĆKO \\ Pracownia Neurobiologii \\ Instytut Biologii Doświadczalnej im. Marcelego Nenckiego PAN \\ Pasteura 3, 02-093 Warszawa \\ E-mail: d.kanigowski@nencki.edu.pl \\ j.ciecko@nencki.edu.pl
}

\title{
OPTOGENETYKA I INNE METODY KONTROLI AKTYWNOŚCI KOMÓREK NERWOWYCH*
}

\section{WSTEP}

Ludzie badaja układ nerwowy już od 5 tysięcy lat, o czym świadczy zachowany staroegipski manuskrypt spisany przez lekarzy tamtych czasów (BRESTEAD 1930). Pierwszy raz pojawia się w nim słowo „mózg”. Natomiast pierwsza znana historii osoba, która stwierdziła, że mózg tworzy świadomość i jest miejscem doznań był Alkmion, pitagorejczyk żyjacy $\mathrm{w}$ połowie $\mathrm{V}$ w. p.n.e. Ten starożytny grecki neuroanatom wygłosił również uwagę mówiąca, że nerw wzrokowy jest ścieżka niosaca światło do mózgu (PANEGYREs i PANEGYRes 2016). Stwierdzenie to jest niemal zgodne $z$ prawda, pomijajac fakt, że nerw wzrokowy nie przewodzi per se kwantów światła, a jedynie informację o nich, w postaci wyładowan elektrycznych w wypustkach komórek, z których się składa. Czego jednak nie zrobiła sama natura, dokonał człowiek. Obecnie wyposażeni jesteśmy w technologię, która umożliwia nam dostarczenie światła do mózgu i sterowanie aktywnościa jego wybranych komórek. Technologia ta to optogenetyka - połaczenie metod optycznych i genetycznych, przy pomocy których jesteśmy w stanie kontrolować aktywność wybranych neuronów in vitro, np. w hodowli komórkowej, jak $\mathrm{i}$ in vivo, $\mathrm{w}$ żywym zwierzęciu, np. w swobodnie poruszajacej się myszy laboratoryjnej (BOYDEN i współaut. 2005). Możliwość precyzyjnego sterowania aktywnościa specyficznych grup komórek, które tworzą określone obwody neuronalne, jest niezbędna do dokładnego zbadania działania ludzkiego mózgu i zrozumienia zależności przycznowo-skutkowej pomiędzy bodźcem płynacym $z$ otoczenia a odpowiedzia $\mathrm{w}$ postaci zachowania zwierzęcia czy człowieka. Powyższe podejście umożliwia również badanie funkcji mózgu „wyższego rzędu" takich jak: emocje, percepcja, uwaga, zdolności poznawcze, racjonalne myślenie czy język. Optogenetyka daje szansę na zbadanie tych funkcji zarówno w zdrowym, jak i w chorym mózgu, w którym aktywność komórek nerwowych jest zaburzona, np. w schizofrenii, depresji, zaburzeniach ze spektrum autyzmu, zaburzeniach obsesyjno-kompulsyjnych czy zaburzeniach stresu pourazowego (HUANG i współaut. 2013, SPARTA i współaut. 2013). To sprawia, że optogenetyka jest nieocenionym narzędziem współczesnej neurobiologii, a w przyszłości być może i medycyny.

Droga do odkrycia optogenetyki nie była jednak łatwa, a sama metoda nie powstała $\mathrm{w}$ oderwaniu od innych technik manipulacji aktywnościa komórek nerwowych. Dlatego pierwszy rozdział poświęcamy krótkiemu opisowi optogenetyki, po czym przechodzimy do chronologicznego opisu najważniejszych metod, które poprzedzaja powstanie współczesnej formy metod optogenetycznych. W następnych rozdziałach prezentujemy historię powstania optogenetyki zachowujac, przy opisie opsyn, kolejność w jakiej były one odkrywane i konstruowane. Końcowy rozdział dedykujemy najnowszym metodom manipulacji aktywnością neuronów, takich jak LITEs czy techniki oparte na nanoczastecz-

Słowa kluczowe: chemogenetyka, nanocząsteczki, opsyny, optogenetyka 
kach. Metody te, czerpiąc $z$ podstaw optogenetyki, wprowadzaja jednocześnie nowatorskie rozwiazania i szkicuja perspektywy dalszego ich wykorzystania w rozwoju neurobiologii.

\section{OPTOGENETYKA}

Optogenetyka opiera się na opanowaniu trzech podstawowych metod badawczych: (1) produkcji opsyn, starej ewolucyjnie rodziny genów pochodzacych od archebakterii i alg. Każdy $z$ tych genów koduje białko, które po wzbudzeniu światłem o odpowiedniej długości fali generuje transbłonowy ruch jonów lub protonów; (2) bogatej puli procedur manipulacji genetycznej, pozwalajacych na wystarczajaco silną ekspresję opsyn w wybranej, specyficznej grupie komórek mózgu; (3) narzędziach pozwalających dostarczyć światło o właściwej długości fali i manipulować siła i czasem trwania jego pulsów (DEISSEROTH 2011).

Za odkrywcę opsyn uznaje się Franza Bolla, który w 1876 r. zaobserwował, że pręciki siatkówki żaby zmieniają kolor po wystawieniu zwierząt na światło różnej barwy (Bolla 1877). Prawie sto lat później odkryto mechanizm działania opsyn u mikroorganizmów. W 1971 r. opisano bakteriorodopsynę pochodzacca od Halobacterium halobium - halofilnej archebakterii zasiedlajacej środowiska o wysokim stężeniu soli (OESTERHELT i STOECKENIUS 1971). Odkryto wtedy, że bakteriorodopsyna pod wpływem światła działa jak pompa jonowa. Dalsze odkrycia białek $\mathrm{z}$ tej rodziny przypadaja na $1977 \mathrm{r}$., kiedy odkryto halorodopsynę (MATSUNO-YAGI i MUKohatA 1977), i 2002 r., kiedy opisano opsynę ChR1 (ang. channelrhodopsin-1) (NAGEL i współaut. 2002). Od chwili odkrycia pierwszej bakteryjnej opsyny, do chwili opublikowania przez Karla Deisserotha i jego zespół $z$ Uniwersytetu Stanforda pracy opisujacej pierwszac optogenetyczna manipulację aktywności komórek nerwowych musiało minać ponad 30 lat (BOYDEN i współaut. 2005). Trzeba jednak zaznaczyć, że sam pomysł manipulacji aktywnościa neuronów za pomoca światła nie był nowy; już w 1979 r. Francis Crick spekulował na ten temat na łamach Scientific American (DEISSEROTH 2010). Dla pełnego obrazu sytuacji należy również wspomnieć o całym wachlarzu wcześniejszych metod jakie powstały przez ostatnie półwiecze dla celów manipulacji aktywnością komórek nerwowych. Metody te sa bardzo różne, zarówno pod względem zasad działania, jak i ich dokładności w czasowo-przestrzennej regulacji aktywności neuronów. Różnią się również pod względem specyficzności, czyli możliwości wybiórczego oddziaływania na określony typ komórek, np. tylko na komórki pobudzające (glutaminergiczne) lub hamujace (GABAergiczne).

\section{PIERWSZE METODY MANIPULACJI AKTYWNOŚCIA KOMÓREK NERWOWYCH}

Do najstarszych prób manipulacji aktywnościa komórek nerwowych należą metody blokujace naturalne przewodnictwo w nerwie przez jego polaryzację za pomoca elektrod (VASTOLA 1961). Inne metody $z$ lat 60. opierały się na zablokowaniu aktywności komórek przez chłodzenie tkanki mózgowej przy użyciu metalowych drutów lub płytek podłaczonych do aparatury chłodzacej (HULL 1968). Równocześnie stosowano farmakologię: wykorzystywane były blokery kanałów sodowych (np. tetrodotoksyna), różnego typu agoniści (np. muscimol) i antagoniści (np. pikrotoksyna) receptorów hamujących GABA-A (NARAHASHI i współaut. 1964, HORI i współaut. 1979). Powyższe związki są nadal szeroko wykorzystywane w badaniach elektrofizjologicznych nad układem nerwowym. Nie umożliwiaja one jednak specyficznej blokady tylko jednej, wybranej klasy komórek. Nieco później, na przełomie lat 80. i 90. eksperymentowano $z$ różnymi chemicznie syntetyzowanymi, „uwięzionymi” (ang. caged) neurotransmiterami, takimi jak: acetylocholina, kwas $\gamma$-aminomasłowy (GABA), glicyna czy glutaminian. W metodzie tej do natywnych neuroprzekaźników, za pomoca wiazań estrowych lub amidowych, przyłaczano niewielkie węglowodory cykliczne. Taki komponent był biologicznie nieaktywny i fotolabilny. Po oświetleniu światłem lasera zwiazki te rozpadały się uwalniajacc „uwięziony”, biologicznie czynny neuroprzekaźnik (WiLcox i współaut. 1990). Były to pierwsze formy stymulacji aktywności komórek nerwowych za pomoca światła. Poczatkowo metoda ta stosowana była do śledzenia funkcjonalnych połączeń pomiędzy neuronami w mózgach ssaków. Wykorzystując metodę „uwięzionego" glutaminianu wraz $z$ metodami elektrofizjologicznymi zmapowano rozwój funkcjonalnych połączeń w korze wzrokowej rozwijajacych się młodych fretek (DALVA i KATZ 1994). Technologia „uwięzionych” neuroprzekaźników intensywnie ewoluowała i dzisiaj jest również szeroko wykorzystywana w badaniach neurobiologicznych nad plastycznością mózgu. „Uwięzione” neuroprzekaźniki, z wykorzystaniem mikroskopii dwufotonowej, umożliwiają obecnie stymulację pojedynczych kolców dendrytycznych w synapsach i badanie szlaków sygnałowych bioracych udział w plastyczności tych struktur (CHANG i współaut. 2019). Niestety stymulacja za pomoca 
„uwięzionych” neuroprzekaźników również nie pozwala na specyficzna manipulacje aktywności wybranej populacji neuronów.

Taka specyficzna kontrolę umożliwiaja dopiero narzędzia biologii molekularnej, polegające na zaplanowanej ekspresji różnego typu genów w wybranych typach komórek. Metody te używają genów zmutowanych, pochodzacych od innych organizmów lub zaprojektowanych od podstaw. Za przykład może posłużyć kierowana ekspresja $z$ wykorzystaniem systemu GAL4/UAS u muchówki, wywilżny karłowatej (Drosophila mela- nogaster). Z wykorzystaniem tego systemu stworzono wywilżny, u których za pośrednictwem zmian temperatury można było sterować aktywnościa wybranych grup komórek. Było to osiagalne przez wprowadzenie do komórek zmutowanego allelu shits ${ }^{\text {s }}$. Gen ten koduje białko odpowiedzialne za endocytozę, a przez to recyrkulację pęcherzyków synaptycznych. Dodatkowo, jego ekspresja regulowana jest przez temperaturę (Tabela 1) (Kitamoto 2001). Pozwoliło to na sterowanie aktywnością neuronów i zachowaniem wywilżn w minutowej skali czasu, a więc wy-

Tabela 1. Wybrane metody manipulacji aktywnością komórek nerwowych.

\begin{tabular}{|c|c|c|c|c|}
\hline Nazwa & Białko, pochodzenie & Stymulacja & Efekt & Bibliografia \\
\hline $\begin{array}{l}\text { Allel shits (mutacja } \\
\text { genu natywnego) }\end{array}$ & $\begin{array}{l}\text { dynamina (GTPaza) } \\
\text { Drosophila melanogaster }\end{array}$ & $>30^{\circ} \mathrm{C}$ & $\begin{array}{l}\text { blokada endocytozy, blok } \\
\text { synaptyczny }\end{array}$ & KITAMOTO 2001 \\
\hline $\begin{array}{l}\text { Lekki łańcuch te- } \\
\text { tanospazmniy - w } \\
\text { postaci transgenu } \\
\text { kodującego to biał- } \\
\text { ko }\end{array}$ & $\begin{array}{l}\text { enzym proteolityczny, } \\
\text { Clostridium tetani }\end{array}$ & $\begin{array}{l}\text { konstytutywna eks- } \\
\text { presja lub doksycy- } \\
\text { klina }\end{array}$ & $\begin{array}{l}\text { przecina WAMP2/synapto- } \\
\text { brewine } 2 \text {, zahamowanie } \\
\text { egzocytozy, blok synap- } \\
\text { tyczny }\end{array}$ & $\begin{array}{l}\text { SWEENEY i } \\
\text { współaut. } 1995 \\
\text { YAMAMOTO i } \\
\text { współaut. } 2003\end{array}$ \\
\hline AlstR & $\begin{array}{l}\text { receptor GPCR regulu- } \\
\text { jący syntezę hormonu } \\
\text { juwenilnego, } \\
\text { D. melanogaster }\end{array}$ & peptyd allatostatyna & $\begin{array}{l}\text { aktywacja kanałów GIRK, } \\
\text { hiperpolaryzacja błony }\end{array}$ & $\begin{array}{l}\text { LECHNER i } \\
\text { współaut. } 2002\end{array}$ \\
\hline chARGe & $\begin{array}{l}\text { trzy białka budujace } \\
\text { fotoreceptor: arestyna-2, } \\
\text { rodopsyna, podjednost- } \\
\text { ka a białka G, } \\
\text { D. melanogaster }\end{array}$ & $\begin{array}{l}\text { światło o długości } \\
\text { fali } 400-600 \mathrm{~nm}\end{array}$ & $\begin{array}{l}\text { uruchomienie kaskady } \\
\text { sygnałowej przez białko } \\
\text { G, aktywacja kanałów ka- } \\
\text { tionowych, depolaryzacja } \\
\text { błony }\end{array}$ & $\begin{array}{l}\text { ZEMELMAN i } \\
\text { współaut. } 2002\end{array}$ \\
\hline TRPV1 & $\begin{array}{l}\text { receptor/kanal katio- } \\
\text { nowy, } \\
\text { Rattus norvegicus }\end{array}$ & kapsaicyna & $\begin{array}{l}\text { aktywacja kanału, depola- } \\
\text { ryzacja błony }\end{array}$ & $\begin{array}{l}\text { ZEMELMAN i } \\
\text { współaut. } 2003\end{array}$ \\
\hline SPARK & $\begin{array}{l}\text { zmodyfikowany kanał } \\
\text { potasowy z kowalen- } \\
\text { cyjnie przyłączanym } \\
\text { fotoczułym związkiem } \\
\text { chemicznym, } \\
\text { D. melanogaster }\end{array}$ & $\begin{array}{l}\text { światło o długości } \\
\text { fali 380 nm - ak- } \\
\text { tywacja; 460-500 } \\
\text { nm - inaktywacja }\end{array}$ & $\begin{array}{l}\text { zmiana konformacji związ- } \\
\text { ku chemicznego, otwarcie } \\
\text { kanału, depolaryzacja } \\
\text { błony }\end{array}$ & $\begin{array}{l}\text { BANGHART i } \\
\text { współaut. } 2004\end{array}$ \\
\hline MIST & $\begin{array}{l}\text { zmodyfikowane białka } \\
\text { odpowiedzialne za egzo- } \\
\text { cytoze, } \\
\text { Rattus norvegicus }\end{array}$ & $\begin{array}{l}\text { podanie związków } \\
\text { chemicznych }\end{array}$ & $\begin{array}{l}\text { dimeryzacja białek, zaha- } \\
\text { mowania egzocytozy, blok } \\
\text { synaptyczny }\end{array}$ & $\begin{array}{l}\text { KARPOVA i } \\
\text { współaut. } 2005\end{array}$ \\
\hline $\begin{array}{l}\text { DREADD: } \\
\text { hM4Di } \\
\text { hM3Dq }\end{array}$ & $\begin{array}{l}\text { Zmodyfikowany muska- } \\
\text { rynowy receptor GPCR } \\
\text { acetylocholiny, } \\
\text { Homo sapiens }\end{array}$ & N-tlenek klozapiny & $\begin{array}{l}\text { aktywacja szlaku sygna- } \\
\text { łowego za pośrednictwem } \\
\text { białka G, hiperpolaryzacja } \\
\text { lub depolaryzacja błony }\end{array}$ & $\begin{array}{l}\text { ARMBRUSTER i } \\
\text { współaut. } 2007 \\
\text { ALEXANDER i } \\
\text { współaut. } 2009\end{array}$ \\
\hline ChR1 & $\begin{array}{l}\text { kanał przepuszczalny } \\
\text { dla jonów wodorowych, } \\
\text { Chlamydomonas rein- } \\
\text { hardtii }\end{array}$ & $\begin{array}{l}\text { światło o długości } \\
\text { fali } \sim 500 \mathrm{~nm}\end{array}$ & $\begin{array}{l}\text { aktywacja kanału, depola- } \\
\text { ryzacja błony }\end{array}$ & $\begin{array}{l}\text { NAGEL i współ- } \\
\text { aut. } 2002\end{array}$ \\
\hline
\end{tabular}




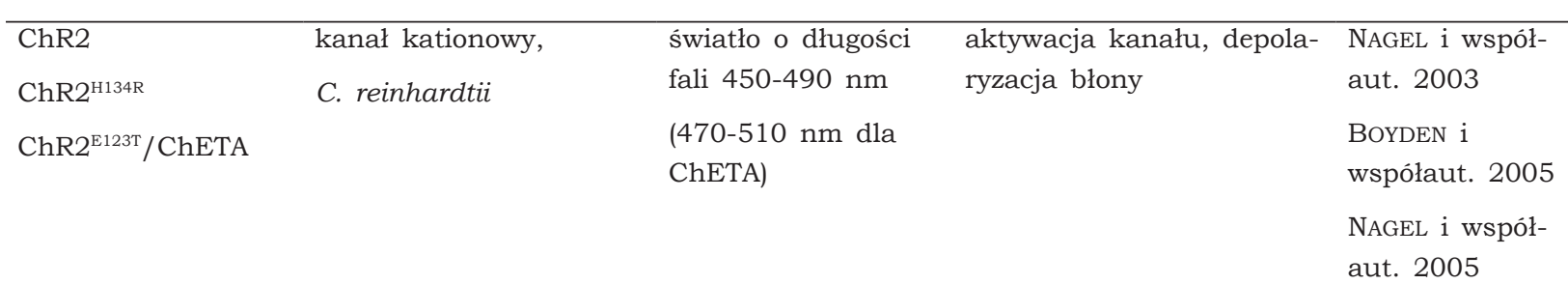

GUNAYDIN i

\begin{tabular}{|c|c|c|}
\hline $\mathrm{RO} 4$ & $\begin{array}{l}\text { rodopsyna, receptor } \\
\text { GPCR działajacy za po- } \\
\text { średnictwem } \mathrm{G}_{\mathrm{i} / \mathrm{o}} \\
\text { R. norvegicus }\end{array}$ & $\begin{array}{l}\text { światło o długości } \\
\text { fali } \sim 475 \mathrm{~nm}\end{array}$ \\
\hline
\end{tabular}

postsynaptyczna aktywacja kanałów GIRK, hiperpolaryzacja błony,

presynaptyczne hamowanie kanałów wapniowych, hamowanie wydzielania neuroprzekaźnika

\begin{tabular}{lllll}
\hline Halo/NpHR & pompa chlorowa, & światło o długości & neuroprzekaźnika & transport anionów chloru \\
eNpHR/eNpHR2.0 & Natronomas pharaonis & fali $560-590 \mathrm{~nm}$ & do wnętrza komórki, hi- & 2007 \\
eNpHR3.0 & & perpolaryzacja błony & $\begin{array}{l}\text { ZHANG i współ- } \\
\text { aut. 2007 }\end{array}$
\end{tabular}

\begin{tabular}{|c|c|c|c|c|}
\hline & & & & \multirow{4}{*}{$\begin{array}{l}\text { aut. } 2007 \\
\text { GRADINARU i } \\
\text { współaut. } 2008 \\
\text { CHOw i współ- } \\
\text { aut. } 2010 \\
\text { GRADINARU i } \\
\text { współaut. } 2010\end{array}$} \\
\hline & & & & \\
\hline & & & & \\
\hline & & & & \\
\hline VChR & $\begin{array}{l}\text { kanał kationowy, } \\
\text { Volvox carteri }\end{array}$ & $\begin{array}{l}\text { światło o długości } \\
\text { fali } 450-490 \mathrm{~nm}\end{array}$ & $\begin{array}{l}\text { aktywacja kanału, } \\
\text { depolaryzacja błony }\end{array}$ & $\begin{array}{l}\text { ERNST i współ- } \\
\text { aut. } 2008\end{array}$ \\
\hline VChR1 & $\begin{array}{l}\text { kanał kationowy, } \\
\text { V. carteri }\end{array}$ & $\begin{array}{l}\text { światło o długości } \\
\text { fali } \sim 535 \mathrm{~nm}\end{array}$ & $\begin{array}{l}\text { aktywacja kanału, } \\
\text { depolaryzacja błony }\end{array}$ & $\begin{array}{l}\text { ZHANG i współ- } \\
\text { atu. } 2008\end{array}$ \\
\hline $\begin{array}{l}\text { Arch/ } \\
\text { ArchT }\end{array}$ & $\begin{array}{l}\text { pompa protonowa, } \\
\text { Halorubrum sodomense, } \\
\text { Halorubrum sp. szczep } \\
\text { TP009 }\end{array}$ & $\begin{array}{l}\text { światło o długości } \\
\text { fali } 525-600 \mathrm{~nm}\end{array}$ & $\begin{array}{l}\text { transport protonów na } \\
\text { zewnątrz komórki, hiper- } \\
\text { polaryzacja błony }\end{array}$ & $\begin{array}{l}\text { CHOW i współ- } \\
\text { aut. } 2010 \\
\text { HAN i współ- } \\
\text { aut. } 2011\end{array}$ \\
\hline $\mathrm{Mac} / \mathrm{LR} / \mathrm{Ops}$ & $\begin{array}{l}\text { pompa protonowa, } \\
\text { Leptosphaeria maculans }\end{array}$ & $\begin{array}{l}\text { światło o długości } \\
\text { fali } 510-570 \mathrm{~nm}\end{array}$ & $\begin{array}{l}\text { transport protonów na } \\
\text { zewnattrz komórki, hiper- } \\
\text { polaryzacja błony }\end{array}$ & $\begin{array}{l}\text { CHOW i wspó1- } \\
\text { aut. } 2010\end{array}$ \\
\hline optoXR & $\begin{array}{l}\text { hybrydy białkowe zło- } \\
\text { żone } \mathrm{z} \text { rodopsyny Bos } \\
\text { taurus i receptora adre- } \\
\text { nergicznego } \mathrm{a}_{1} \\
H \text {. sapiens lub recep- } \\
\text { tora adrenergicznym } \beta_{2} \\
\text { Mesocricetus auratus }\end{array}$ & $\begin{array}{l}\text { światło o długości } \\
\text { fali } \sim 470-500 \mathrm{~nm}\end{array}$ & $\begin{array}{l}\text { aktywacja kaskady sy- } \\
\text { gnałowej: receptor } \mathrm{a}_{1} \text { za } \\
\text { pośrednictwem } \mathrm{G}_{\mathrm{q}} \text {, depo- } \\
\text { laryzacja błony; receptor } \\
\beta_{2} \text { za pośrednictwem } \mathrm{G}_{\mathrm{s}} \text {, } \\
\text { hiperpolaryzacja błony }\end{array}$ & $\begin{array}{l}\text { AIRAN i współ- } \\
\text { aut. } 2009\end{array}$ \\
\hline C1V1 & $\begin{array}{l}\text { hybryda białkowa ChR1 } \\
\text { C. reinhardtii i VChR1 } \\
\text { V. carteri }\end{array}$ & $\begin{array}{l}\text { światło o długości } \\
\text { fali } \sim 1040 \mathrm{~nm}\end{array}$ & $\begin{array}{l}\text { aktywacja kanału, depola- } \\
\text { ryzacja błony }\end{array}$ & $\begin{array}{l}\text { PRAKASH i } \\
\text { współaut } 2012 \\
\text { RICKGAUER i } \\
\text { współaut. } 2014 \\
\end{array}$ \\
\hline
\end{tabular}
2005

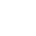

współaut. 2010 


\begin{tabular}{|c|c|c|c|c|}
\hline LITEs & $\begin{array}{l}\text { hybrydy białkowe zło- } \\
\text { żone z motywuw TALE } \\
\text { Xanthomonas sp., } \\
\text { dwóch białek CRY2 i } \\
\text { CIB1 Arabidopsis tha- } \\
\text { liana oraz białek efek- } \\
\text { torowych: syntetycznego } \\
\text { VP64 na bazie jednego } \\
\text { z białek Herpes sim- } \\
\text { plex virus i drugiego } \\
\text { SID4X na bazie jednego } \\
\text { z białek A. thaliana }\end{array}$ & $\begin{array}{l}\text { światło o długości } \\
\text { fali } 350-475 \mathrm{~nm}\end{array}$ & $\begin{array}{l}\text { zmiana konformacji CRY2, } \\
\text { przyłączenie CIB1 do } \\
\text { CRY2; VP64 - aktywacja } \\
\text { transkrypcji, SID4X - po- } \\
\text { średnictwo w deacetylacji } \\
\text { histonów, represja trans- } \\
\text { krypcji }\end{array}$ & $\begin{array}{l}\text { KONERMANN i } \\
\text { współaut. } 2013\end{array}$ \\
\hline $\begin{array}{l}\text { TRPV1 i nanocząst- } \\
\text { ki } \mathrm{Fe}_{3} \mathrm{O}_{4} \varnothing 22 \mathrm{~nm}\end{array}$ & $\begin{array}{l}\text { receptor/kanał kationo- } \\
\text { wy, } R . \text { norvegicus }\end{array}$ & $\begin{array}{l}\text { pole magnetycz- } \\
\text { ne, oddanie ciepła } \\
\text { przez cząstki w wy- } \\
\text { niku magnetycznej } \\
\text { histerezy, }>43^{\circ} \mathrm{C} \\
\end{array}$ & $\begin{array}{l}\text { aktywacja kanału, depola- } \\
\text { ryzacja błony }\end{array}$ & $\begin{array}{l}\text { CHEN i współ- } \\
\text { aut. } 2015\end{array}$ \\
\hline $\begin{array}{l}\text { nanocząstki złota } \\
\varnothing 20 \mathrm{~nm} \text { skoniugo- } \\
\text { wane z II-rzędowymi } \\
\text { przeciwciałami }\end{array}$ & - & $\begin{array}{l}\text { światło o długości } \\
\text { fali } \sim 523 \mathrm{~nm}\end{array}$ & $\begin{array}{l}\text { wypromieniowanie ener- } \\
\text { gii przez nanocząsteczki } \\
\text { w postaci ciepła, zmiana } \\
\text { pojemności elektrycznej } \\
\text { błony generuje prąd po- } \\
\text { jemnościowy, depolaryza- } \\
\text { cja błony }\end{array}$ & $\begin{array}{l}\text { CARVALHO-DE- } \\
\text {-SOUZA i współ- } \\
\text { aut. } 2015\end{array}$ \\
\hline $\begin{array}{l}\text { nanoczastki NaY- } \\
\mathrm{F} 4: \mathrm{Yb}^{3+} / \mathrm{Tm}^{3+} \\
\mathrm{NaYF} 4: \mathrm{Yb}^{3+} / \mathrm{Er}^{+3} \\
\text { i opsyny ChR2, } \\
\text { Arch }\end{array}$ & $\begin{array}{l}\text { kanal kationowy, } \\
\text { C. reinhardtii, } \\
\text { pompa protonowa, } \\
\text { H. sodomense }\end{array}$ & $\begin{array}{l}\text { światło o długości } \\
\text { fali } \sim 980 \mathrm{~nm}\end{array}$ & $\begin{array}{l}\text { pochłonięcie przez nano- } \\
\text { cząstkę niskoenergetycz- } \\
\text { nych fotonów i wypromie- } \\
\text { niowanie fotonu o wyższej } \\
\text { energii, aktywacja ChR2 } \\
\text { i depolaryzacja błony lub } \\
\text { aktywacja Arch i hiperpo- } \\
\text { laryzacja błony }\end{array}$ & $\begin{array}{l}\text { CHEN i współ- } \\
\text { aut. } 2018\end{array}$ \\
\hline
\end{tabular}

wołanie $\mathrm{u}$ nich temperaturowo-zależnego paraliżu lub ich oślepienia. $Z$ wykorzystaniem systemu GAL4/US udało się również zahamować przekaźnictwo synaptyczne w wybranych komórkach tych muchówek przez ekspresję genu kodującego lekki łańcuch białka tetanospazminy, groźnej toksyny pochodzacej od laseczki tężca (Clostridium tetani) (SWEENEY i współaut. 1995). Lekki łańcuch tetanospazminy jest odpowiedzialny za cięcie białka VAMP2/synaptobrewina 2, które związane jest $z$ membrana pęcherzyków synaptycznych. VAMP2 odpowiedzialne jest za proces dokowania pecherzyka synaptycznego do błony presynaptycznej i jego fuzję $z$ błona. Jest to więc jedno $z$ białek bioracych udział $\mathrm{w}$ procesie egzocytozy pecherzyka synaptycznego i uwolnienia neuroprzekaźnika do szczeliny synaptycznej.

Przy wykorzystaniu metod indukowanej ekspresji udało się później stworzyć linię myszy eksprymujacych lekki łańcuch tetanospazminy w zależności od obecności antybiotyku doksycykliny (YАMAMOTO i wspó1aut. 2003). Podając myszom ten antybiotyk w pożywieniu i wodzie udało się indukować ekspresję lekkiego łańcucha tetanospazminy w komórkach ziarnistych móżdżku. W ten sposób można było hamować uwalnianie glutaminianu przez komórki ziarniste, co prowadziło do znacznego pogorszenia wyników w testach na koordynacje ruchowa gryzoni traktowanych doksycyklina. Efekt ten był odwracalny po zaprzestaniu podawania antybiotyku.

\section{NOWE METODY MANIPULACJI AKTYWNOSCIA KOMÓREK NERWOWYCH}

W wyniku metodycznych poszukiwań pojawiło się wiele technik mających na celu kontrolowanie aktywności neuronów. Stosunkowo nowym podejściem jest wykorzystanie chemogenetyki. Metoda ta polega na genetycznej manipulacji pozwalającej na ekspresję w docelowych komórkach genów kodujących specjalnie zaprojektowane, transbłonowe białka receptorowe, reagujace na wybrane niewielkie zwiąki chemicz- 
ne. Białka te w obecności swoich ligandów zmieniaja własna konformację i $\mathrm{w}$ różnorodny sposób wpływają na aktywność komórek, w których sa eksprymowane. Jednym z pierwszych tego typu podejść było użycie do regulacji aktywności ssaczych neuronów receptora AlstR pochodzacego $z$ D. melanogaster. AlstR należy do receptorów sprzężonych $z$ białkiem G (ang. G protein-coupled receptor, GPCR), natywnie odpowiada za regulacje syntezy hormonu juwenilnego owadów i jest aktywowany przez niewielki peptyd, allatostatynę. Receptor ten, w neuronach ssaków, po podaniu egzogennej allatostatyny, aktywuje sprzężone $z$ białkiem $G$ wewnątrzprostownicze kanały potasowe (ang. G protein-coupled inwardly-rectifying potassium channels, GIRKs), które po otwarciu powoduja hiperpolaryzacje komórki i zmniejszaja w ten sposób prawdopodobieństwo wystapienia potencjałów czynnościowych (LECHNER i współaut. 2002).

Kolejnym krokiem na długiej drodze rozwoju metod i technologii kontroli aktywności komórek nerwowych było wykorzystanie światła, w połaczeniu $\mathrm{z}$ narzędziami transformacji genetycznej. Nie były to stricte metody optogenetyczne $\mathrm{w}$ dzisiejszym rozumieniu. Wykorzystywały one światło do bezpośredniej aktywacji genetycznie i chemicznie modyfikowanych białek lub pośrednio, przez "uwięzione" ligandy. Można jednak z pewnościa powiedzieć, że byly to pewne prekursorowe metody optogenetyczne. Znacznie bardziej skomplikowane i trudniejsze $w$ realizacji, a także mniej efektywne niż właściwa optogenetyka. Mimo swoich niedoskonałości pokazały jednak, że przy pomocy światła można selektywnie sterować aktywnościa wybranej populacji neuronów. Do pierwszych tego typu metod należy metoda chARGe, wykorzysujaca geny kodujace fotoreceptor wywilżny karłowatej: arrestynę-2, rodopsynę i podjednostke a białka G. Eksprymowana opsynę należało dodatkowo rekonstytuować, dodając do układu całkowity-trans-retinal (chromofor), który kowalencyjnie łączy się z tym białkiem i nadaje mu pełna funkcjonalność w absorbcji światła. Eksprymując trzy powyższe geny $\mathrm{w}$ szczurzych neuronach hipokampalnych w obecności retinalu można było, z mniejsza lub większą skutecznościa, wzbudzać potencjały czynnościowe za pomoca światła (ZEMELMAN i współaut. 2002). Wszystkie powyżej opisane metody transformacji genetycznej i kontroli aktywności komórkowej nie pozwalały jednak na skuteczna, efektywna i czasowo-specyficzna kontrolę potencjałów czynnościowych w komórkach nerwowych.

Dopiero w 2003 r., przy wykorzystaniu receptora waniloidowego (ang. vanilloid re- ceptor, TRPV1) wraz $\mathrm{z}$ technologia „uwięzionych" ligandów, rzeczywiście możliwe stało się stosunkowo precyzyjne sterowanie aktywnościa komórek nerwowych. Receptor waniloidowy jest nieselektywnym kanałem kationowym, który normalnie występuje w neuronach nocyceptywnych (receptorach bólowych) obwodowego układu nerwowego. W obecności swojego ligandu, kapsaicyny, receptor ten powoduje depolaryzację błony komórkowej. Eksprymujac ten receptor w szczurzych neuronach hipokampalnych i jednocześnie stosując „uwięzioną" kapsaicyne, potwierdzono skuteczność tego rozwiazania (ZEMELMAN i współaut. 2003). Metoda ta (receptor-,„uwięziony” ligand) posłużyła m.in. do manipulacji zachowaniem wywilżny i mapowania jej obwodów neuronowych. Badając proste obwody neuronalne odpowiedzialne za stereotypowe zachowania ruchowe tego owada i kontrolując pewne grupy neuronów w jego tułowiu, zaprezentowano lot bezgłowego korpusu muchówki (LIMA i MIESENBÖCK 2005).

Następnym, interesującym i kreatywnym podejściem był system SPARK (ang. synthetic photoisomerizable azobenzene-regulated $\mathrm{K}^{+}$channels) wykorzystujacy do kontroli komórek genetycznie zmodyfikowany kanał potasowy wraz $z$ przyłączonym do niego kowalencyjnie specyficznym zwiazkiem chemicznym (BANGHART i współaut. 2004). Zwiazek ten, pod wpływem fal światła różnej długości, zmieniał swoja konformację i długość cząsteczki. W swojej dłuższej konfiguracji trans był zdolny zatykać zewnatrzkomórkową stronę kanału, blokując przepływ jonów potasu. Natomiast po wzbudzeniu światłem ultrafioletowym, czasteczka zmniejszała swoją długość o ok. 7 angstremów, nie sięgała wylotu kanału i nie blokowała przepływu jonów potasu (BANGHART i współaut. 2004).

Kolejne lata przyniosły powstanie i szybki rozwój metod optogenetycznych do postaci, jaka dzisiaj znamy - wykorzystujacych opsyny archebakterii $i$ alg. Jednocześnie $z$ rozkwitem tych metod, postępował rozwój chemogenetycznej kontroli komórek nerwowych. W 2005 r. opublikowano metodę MIST (ang. molecules for inactivation of synaptic transmission), pozwalająca zablokować cykl obiegu pęcherzyków synaptycznych i zatrzymać uwalnianie neuroprzekaźników do szczeliny synaptycznej. Metoda ta bazuje na genetycznie zmodyfikowanych białkach synaptycznych, które w obecności właściwych cząsteczek chemicznych dimeryzuja (łącza się w pary), w wyniku czego nie moga dalej pełnić swojej funkcji (KARPOVA i współaut. 2005).

W 2007 r. opisano kolejny system, DREADD (ang. designer receptors exclusively activated by designer drugs), umożliwiaja- 
cy kontrolę aktywności neuronów za pomoca genetycznie zmodyfikowanych białek GPCR ludzkich receptorów muskarynowych dla acetylocholiny. Receptory te moga być aktywowane przez specjalnie zaprojektowany, nowy zwiazek chemiczny N-tlenek klozapiny (ang. clozapine-N-oxide, CNO), będac jednocześnie niewrażliwymi na swój natywny ligand, acetylocholinę, ani na jej syntetyczna pochodna, karbachol (ARMBRUSTER i współaut. 2007). Jednym z białek wykorzystanym przy konstrukcji nowych receptorów był ludzki muskarynowy receptor acetylocholiny hM4, który działa za pośrednictwem

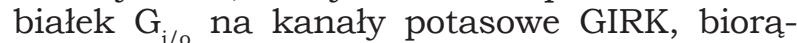
ce udział $\mathrm{w}$ hiperpolaryzacji błony komórki. Dwie punktowe mutacje w wybranych miejscach łańcucha aminokwasowego receptora hM4 pozwoliły na skonstruowanie receptora hM4Di niewrażliwego na acetylocholinę, a reagującego na CNO. Eksprymujacc hM4Di $\mathrm{w}$ warunkach in vitro $\mathrm{w}$ szczurzych neuronach hipokampalnych i wprowadzajac CNO do roztworu można było hiperpolaryzować te komórki o ok. $7 \mathrm{mV}$. Powyższy stopień hiperpolaryzacji był wystarczajacy do zablokowania spontanicznych wyładowań tych komórek. Ponadto, receptor hM4Di nie wykazywał aktywności przy braku CNO, a jego ekspresja w komórkach nie zmieniała podstawowych własności elektrofizjologicznych błony neuronalnej (ARMBRUSTER i współaut. 2007).

Genetycznie zmodyfikowane ludzkie receptory muskarynowe dla acetylocholiny wykorzystuje się również do aktywacji komórek nerwowych. Receptor hM3, działajacy za pośrednictwem białek Gq, posłużył do stworzenia zmutowanego receptora hM3Dq, który, podobnie jak hM4Di, nie reagował na acetylocholinę, a był wrażliwy na CNO (ARMBRUSTER i współaut. 2007). Zmutowane białko posłużyło np. do stworzenia transgenicznej linii myszy, eksprymującej hM3Dq w neuronach pobudzajacych kory, hipokampa i prążkowia (ALEXANDER i współaut. 2009). Dodanie CNO podczas rejestracji elektrofizjologicznych w skrawkach mózgowych pochodzacych od myszy eksprymujacych hM3Dq prowadziło do depolaryzacji neuronów piramidalnych hipokampa o ok. $8 \mathrm{mV}$, a także zwiększało częstotliwość spontanicznych potencjałów czynnościowych tych komórek. Podanie dootrzewnowe CNO powodowało $\mathrm{u}$ myszy zwiększona lokomocję i wzrost zachowań stereotypowych, utrzymujace się przez 9 godzin po zastrzyku. Rejestracje elektrofizjologiczne za pomoca elektrod wprowadzanych do mózgów tych myszy pokazały natomiast, że już 5-10 minut po dootrzewnowym podaniu CNO, zwiększa się aktywność neuronów hipokampa (ALEXANDER i współaut. 2009).
Wszystkie powyżej wymienione metody chemogenetyczne, pomimo wielu swoich zalet, nie pozwalaja jednak na sterowanie aktywnością neuronów $z$ precyzją milisekundową, jaką można osiągnąć stosujacc techniki optogenetyczne. Również w metodach chemogenetycznych, odpowiedzi neuronów sa niejednorodne w obrębie grupy stymulowanych komórek, jak i w kolejnych powtórzeniach podawania liganda. Metody chemogenetyczne sa jednak latwiejsze i nie wymagaja użycia drogich, zawansowanych technologicznie narzędzi do kontroli pulsów światła. Tam, gdzie nie jest wymagana milisekundowa precyzja w kontroli aktywności neuronów, moga stanowić optymalne rozwiazanie.

\section{OPSYNY}

Wracajac do optogenetyki: w 2002 r. Georg Nagel $z$ Instytutu Maxa Plancka wraz ze współpracownikami (NAGEL i współaut. 2002) opublikował doniesienie, w którym przedstawił sekwencje DNA $z$ jednokomórkowej algi Chlamydomonas reinhardtii. Sekwencja ta bardzo przypomina DNA kodujące opsyny bakteryjne. Eksprymujac ten fragment DNA w oocytach platany szponiastej (Xenopus laevis) udowodniono, że rzeczywiście koduje on funkcjonalną opsynę, kanał, który po wzbudzeniu światłem zielonym staje się przepuszczalny dla jonów wodorowych. Opsynę tę opisano skrótem ChR1, a autorzy raportu już wtedy sugerowali możliwość jej wykorzystania w sterowanej światłem manipulacji gradientem elektrycznym w poprzek błony komórkowej. W kolejnym roku zespół Nagela opublikował pracę (NAGEL i współaut. 2003), w której zaprezentowano działanie drugiej opsyny, ChR2 (ang. channelrhodopsin-2), w oocytach platany szponiastej oraz ludzkich i chomiczych liniach komórkowych. Opsyna ta okazała się być kanałem o bardzo szybkiej kinetyce działania. Kanałem, który po wzbudzeniu światłem niebieskim (450-490 nm), generował stosunkowo duży prą kationowy i dzięki temu mógł depolaryzować komórki, zwiększając w ten sposób szansę na wywołanie potencjału czynnościowego. Niecałe dwa lata później odkrywcy opsyny ChR2, we współpracy $z$ zespołem Karla Daisseroth'a, opublikowali pierwsza udana transformację szczurzych neuronów hipokampalnych w hodowli komórkowej za pomoca wektorów lentiwirusowych kodujących nowo opisana opsynę. Stało się wtedy jasne, że ekspresja tylko tej jednej opsyny jest w zupełności wystarczająca do wywołania potencjałów czynnościowych w stymulowanych światłem komórkach nerwowych. Procedura ta nie wymaga również podawania całkowitego-trans-retinalu, ponieważ jak się 
okazało, występuje on naturalnie w cytoplazmie komórek układu nerwowego (BOYDEN i współaut. 2005). Ponadto, ekspresja opsyny ChR2 była stabilna przez kilka tygodni po transformacji i nie zmieniała podstawowych parametrów elektrofizjologicznych błony komórkowej. Wskazywało to na brak cytotoksyczności tego białka i świadczyło o tym, że jest ono aktywne jedynie po wzbudzeniu światłem. Kilka miesięcy później została opublikowana praca opisujaca wykorzystanie opsyny ChR2 wraz ze szczurza rodopsyna 4 (ang. rhodopsin 4, RO4) (LI i współaut. 2005). Białko RO4 należy do rodziny rodopsyn kręgowców, które są receptorami GPCR, działajacymi postsynaptycznie za pośrednictwem białek $G_{i}$ na kanały GIRK hiperpolaryzujące błonę komórki oraz presynaptycznie na kanały wapniowe, blokując napływ jonów wapnia do komórki presynaptycznej. Zmniejszone stężenie jonów wapnia jest czynnikiem hamującym egzocytozę neuroprzekaźników. Aktywność RO4 w dwojaki sposób prowadzi więc do hamowania aktywności komórki nerwowej. W pracy tej, przy użyciu technik optogenetycznych udało się po raz pierwszy dokonać dwukierunkowej manipulacji aktywnościa komórek nerwowych (aktywacja/hamowanie). Oprócz tego, eksprymujac opsynę ChR2 za pomoca elektroporacji w rdzeniu nerwowym kurzych embrionów, udało się w nim zwiększyć częstotliwość spontanicznych, rytmicznych wyładowań. Zwiększenie częstotliwości tych, naturalnie występujących wyładowań w rdzeniu kręgowym kurzego embrionu, prowadziło $z$ kolei do zwiększenia częstotliwości ruchów osiowych samego embrionu in ovo. Doświadczenie to było pierwszym przykładem optogenetycznej manipulacji zachowaniem żywego organizmu. W badaniach tych ujawniono jednocześnie, że światło niebieskie wystarczająco skutecznie penetruje owodnię i tkankę samego embrionu, aby uaktywnić opsynę ChR2, co było dobrym prognostykiem dla dalszego wykorzystania tej opsyny $\mathrm{w}$ badaniach in vivo.

Następnie Nagel we współpracy $z$ naukowcami z Frankfurtu opublikował prace dowodzaca, że przy wykorzystaniu technik optogenetycznych można manipulować również zachowaniem prostego organizmu modelowego, jakim jest jednomilimetrowej długości nicień Caenorhabditis elegans (NAGEL i współaut. 2005). Eksprymujac ulepszona wersje ChR2 ( $\mathrm{z}$ mutacja punktowa w miejscu 134 aminokwasu - ChR2 $\left.{ }^{\mathrm{H} 134 \mathrm{R}}\right)$ w komórkach mięśniowych $C$. elgans można było za pomoca światła wywoływać skurcze mięśni, które prowadziły do kurczenia się tego nicienia i składania przez niego jaj. Nowa ChR2 ${ }^{\mathrm{H} 134 \mathrm{R}}$ wykazywała większa stabilność w przewodzeniu prąów jonowych w stosun- ku do pierwotnej, niezmutowanej formy tego białka. Ekspresja opsyny ChR2 ${ }^{\mathrm{H} 134 \mathrm{R}} \mathrm{w}$ mechanoreceptorach tego zwierzęcia pozwalała wywoływać odruch cofania jego głowy, reakcje naturalnie występujaca $\mathrm{w}$ chwili napotkania przeszkody mechanicznej. Manipulacje zachowaniem nicienia były możliwe jedynie przy diecie wzbogaconej w całkowity-trans-retinal.

Kolejne lata przyniosły niebywale szybki rozwój metod optogenetycznych. Wiele grup badawczych $z$ całego świata zaczęło wykorzystywać optogenetykę $\mathrm{w}$ badaniach nad układem nerwowym, ponieważ umożliwia ona aktywację lub hamowanie aktywności elektrycznej komórek nerwowych $z$ milisekundowa precyzją. Szybki wzrost zainteresowania optogenetyka doprowadził również do szeroko zakrojonych poszukiwań w świecie bakterii, alg i grzybów nowych białek, które miałyby podobna funkcję jak opsyna ChR2. Świat nauki wiedział, że dla dalszego rozwoju optogenetyki niezbędne jest znalezienie lub stworzenie za pomoca narzędzi inżynierii genetycznej nowych receptorów światła. Światłoczułych kanałów, charakteryzujacych się różnorodną selektywnościa względem jonów, reaktywnością na różne długości fali światła, szybszą kinetyka aktywacji, krótszym czasem inaktywacji, czy większą przewodnościa. Poczatkowo eksperymentowano $z$ poznana już w 1977 r. halorodopsyna (ang. halorhodopsin, Halo/NpHR), będaca pompa transportująca do wnętrza komórki aniony chloru po wzbudzeniu żółtym światłem (560-590 nm). Białko to pochodzi od archebakterii Natronomas pharaonis zasiedlajacej środowiska o wysokim stężeniu jonów chlorkowych i umożliwia jej utrzymanie właściwego ciśnienia osmotycznego i zmniejszenie wydatków energetycznych przez pompowanie anionów chloru do wnętrza komórki przeciw gradientowi potencjału elektrycznego błony (HAN i BOYDEN 2007, ZHANG i wspólaut. 2007). Eksprymujacc halorodopsynę w szczurzych neuronach hipokampa można było zmniejszać aktywność tych komórek przez hiperpolaryzacje ich błony za pomoca żółtego światła. Halorodopsyna okazała się mieć równie szybka kinetykę i czułość jak opsyna ChR2 - $1 \mathrm{~ms}$ puls żółtego światła prowadził do hiperpolaryzacji błony komórkowej o kilka miliwoltów i zmniejszał prawdopodobieństwo wywołania potencjału czynnościowego. Jednoczesna ekspresja ChR2 i NpHR pozwoliła po raz pierwszy na dwukierunkowa manipulację aktywnościa komórek nerwowych $z$ prawdziwie milisekundowa kinetyka, znacznie szybciej niż szczurza rodopsyna 4 działajaca metabotropowo za pośrednictwem białka G. Halorodopsyna okazała się pięć razy szybsza w aktywacji hi- 
perpolaryzującego prądu, 90 razy szybsza w jego deaktywacji po zakończeniu stymulacji swiatłem i generowała ponad 3,5 razy większą hiperpolaryzacje niż szczurza rodopsyna 4. Komórki posiadajace w swojej błonie ChR2 i NpHR można było bez przeszkód na przemian depolaryzować i hiperpolaryzować z częstotliwościa $2,5 \mathrm{~Hz}$, przeplatając stymulację niebieskim i żółtym światłem. Dodatkowo, NpHR w komórkach ssaków, tak jak ChR2, nie wymagała wprowadzania do układu dodatkowego kofaktora - całkowitego-trans-retinalu (HAN i BOYDEN 2007). Z kolei NpHR eksprymowana wspólne $z$ ChR2 w mysich neuronach korowych skutecznie blokowała depolaryzacje wywoływana niebieskim światłem. Natomiast eksprymowana w komórkach mięśniowych i cholinergicznych neuronach ruchowych C. elegans, po zastymulowaniu żółtym światłem hamowała ruch tego nicienia. Przy jednoczesnej ekspresji ChR2 i NpHR w mięśniach lub neuronach ruchowych, NpHR hamowała kurczenie się zwierzęcia wywoływane stymulacją niebieskim światłem ChR2. Eksperyment ten pokazał, że prad hamujacy generowany przez NpHR skutecznie znosi aktywność ChR2 zarówno $\mathrm{w}$ komórkach $\mathrm{z}$ hodowli in vitro, jak i w żywym zwierzęciu. Jednak NpHR, tak samo jak ChR2, była w pełni funkcjonalna tylko w nicieniach utrzymywanych w środowisku $z$ dodatkiem całkowitego-trans-retinalu (ZHANG i współaut. 2007).

Mimo dużej skuteczności NpHR, zarówno $\mathrm{w}$ eksperymentach in vitro jak $\mathrm{i}$ in vivo, pewne techniczne ograniczenia nadal pozostały. Niedługo okazało się, że NpHR tworzy agregaty $\mathrm{w}$ siateczce śródplazmatycznej, które potencjalnie moga być cytotoksyczne i dodatkowo sa skutkiem ograniczonej ekspresji tego białka w błonie komórki. W tym celu przetestowano kilkanaście sekwencji sygnałowych z N- i C-końcach różnych białek wydzielanych przez siateczke śródplazmatyczna i transportowanych do błony komórki. Dodajac aminokwasy sekwencji sygnałowej C-końca białka Kv1.4, będacego kanałem błonowym, i N-końca podjednostki $\beta$ receptora nikotynowego acetylocholiny do pierwotnego białka halorodopsyny, można było całkowicie wyeliminować agregację tej opsyny w siateczce śródplazmatycznej (GRADINARU i współaut. 2008). Ta ulepszona forma NpHR dostała dwie równoprawne nazwy: eNpHR i eNpHR2.0 (ang. enhanced NpHR). Nowa opsyna, w stosunku do swojej wyjściowej formy, była w stanie generować niemal dwukrotnie większy prąd transbłonowy w neuronach hipokampalnych hodowli komórkowej. Dodatkowo, podstawowy opór elektryczny błony nie różnił się pomiędzy komórkami Z NpHR i eNpHR2.0. Podobnie jednak jak wie- le naturalnych form hamowania komórek nerwowych, również hamowanie optogenetyczne może zostać przełamane przez bardzo silną aktywność pobudzającą. Aby rozwiąać ten problem i stworzyć opsynę o jeszcze silniejszej możliwości blokowania aktywności komórek nerwowych podejmowano próby $Z$ wykorzystaniem różnych sekwencji sygnałowych $z$ N- i C- końca dwóch wewnatrzprostowniczych kanałow potasowych (ang. inwardly-rectifying potassium channels, IRKs): Kir2.1 i Kir2.4. Dodajac sekwencję sygnałowa odpowiedzialna za kierowanie nowopowstałego białka do błony cytoplazmatycznej z C-końca białka Kir2.1 do eNpHR można było ulepszyć ekspresję tej opsyny w błonie komórkowej, zwłaszcza w neurytach. Ta ulepszona forma halorodopsyny, nazwana eNpHR3.0, generowała 20 razy większy prąd hiperpolaryzujacy $\mathrm{w}$ porównaniu ze swoją wyjściowa, natywna forma NpHR (GRADINARU i współaut. 2010). Prad generowany przez eNpHR3.0 może zmienić potencjał błonowy nawet o $100 \mathrm{mV}$. Dzięki tak dużej przewodności tej pompy osiagalne stało się wykorzystanie słabszego, czerwonego spektrum jej aktywacji (630-680 nm). Pozwoliło to na bardziej selektywną aktywację i hamownie komórek zawierajacych jednocześnie aktywujaca i hamujaca opsynę, odpowiednio ChR2 i eNpHR3.0.

Jednocześnie poszukiwano innych opsyn, podobnych do ChR2, ale $z$ innym widmem absorbcji. Na poczatku 2008 r. opisano pierwszą opsynę pochodzaca od Volvox carteri, algi tworzacej półmilimetrowej średnicy sferyczne kolonie składajace się $z$ kilku tysięcy komórek. Ta nowa opsyna, nazwana Volvox channelrhodopsin (VChR), wykazywała funkcjonalne podobieństwo do wcześniej opisanych dwóch rodopsyn $C$. reinhardtii, $z$ większym podobieństwem do ChR2 (ERNST i współaut. 2008). VChR jest podobna do ChR2 zarówno pod względem widma absorpcji, jak i dynamiki kinetycznej, przez co nie była obiecujacym kandydatem do dalszych testów. W tym samym jednak roku udało się zidentyfikować inną opsynę pochodzaca od $V$. carteri, Volvox channelrhodopsin 1 (VChR1). VChR1 była bardziej podobna do ChR1, a chociaż jej maksymalna absorpcja przypadała również w świetle zielonym, całe widmo pochłaniania było przesunięte bardziej w stronę czerwieni (ZHANG i współatu. 2008). Co ciekawe, za przesunięcie absorbcji widma VChR1 w stosunku do ChR1 i ChR2 odpowiedzialne sa trzy substytucje aminokwasowe względem ich łańcuchów, w rejonie wiążącym pierścień węglowy retinalu i jedna substytucja względem łańcucha peptydowego ChR2 w rejonie oddziaływujacym $z$ atomem azotu ugrupowania iminowego, w miejscu 
kowalencyjnego wiąania retinalu $z$ opsyna. To powoduje zmianę rozkładu ładunku w cząsteczce retinalu i zwiększenie jej polarności, czego następstwem jest absorpcja fotonów o mniejszej energii $\mathrm{w}$ widmie zielono-żółtym $(\sim 535 \mathrm{~nm})$. VChR1 nie różni się pod względem selektywności w stosunku do ChR2 (głównie przepuszcza $\mathrm{Na}^{+}$, ale też $\mathrm{H}^{+}$, $\mathrm{K}^{+} \mathrm{i} \mathrm{Ca}^{2+}$ ), nie zmienia podstawowych właściwości elektrofizjologicznych błony, wykazuje podobna lokalizację przestrzenną w komórce i również nie wymaga dodatkowej suplementacji całkowitym-trans-retinalem w neuronach ssaków (ZHANG i współatu. 2008). VChR1 posiada jednak dużo wolniejsza kinetyke dezaktywacji w stosunku do ChR2; czas ten przy badanej długości światła 531 $\mathrm{nm}$ dla obydwu białek wynosi odpowiednio 133 i $12 \mathrm{~ms}$. Dobierajac fale odpowiedniej długości $(406 \mathrm{~nm}$ dla ChR2 i $589 \mathrm{~nm}$ dla VChR1) i intensywność światła można było $\mathrm{w}$ warunkach in vitro selektywnie wywoływać potencjały czynnościowe $\mathrm{w}$ komórkach $\mathrm{z}$ VChR1, nie stymulujacc w tym samym czasie komórek z ChR2, ponieważ światło o długości fali $589 \mathrm{~nm}$ nie aktywuje ChR2. Niestety stymulacja ChR2 światłem o długości fali $406 \mathrm{~nm}$ również $\mathrm{w}$ niewielkim stopniu wzbudzała potencjały czynnościowe w komórkach z VChR1, ze względu na czesściowa absorpcję światła niebieskiego przez VChR1.

Oprócz szeroko zakrojonych poszukiwań nowych opsyn, starano się również ulepszyć już te poznane. Przykładem tego drugiego podejścia może być udoskonalona forma ChR2 $\mathrm{z}$ substytucja jednego aminokwasu: ChR2 ${ }^{\mathrm{E} 123 \mathrm{~T}}$, w skrócie ChETA (GUNAYDIN i współaut. 2010). Ta ulepszona opsyna wykazuje znacznie szybsza kinetykę dezaktywacji wynoszaca $5.2 \mathrm{~ms}$ w stosunku do $9.8 \mathrm{~ms}$ dla wyjściowej formy ChR2. Dzięki tej zmianie realna stała się optogenetyczna stymulacja komórek nerwowych $z$ częstotliwością sięgająca nawet $200 \mathrm{~Hz}$, znacznie przekraczająca dotychczasowa bariere 40 $\mathrm{Hz}$ dla natywnej formy tego białka. ChETA umożliwiła efektywniejszą stymulację neuronów o bardzo wysokiej, naturalnej częstotliwości, np. szybko wyładowujących się interneuronów (ang. fast-spiking). Również przy niższych częstotliwościach stymulacji, ChETA okazała się być bardziej niezawodna niż ChR2. Nie powodowała artefaktów stymulacji $\mathrm{w}$ postaci dodatkowych, niezamierzonych potencjałów czynnościowych, czy przedłużonej repolaryzacji po ciagu wyładowań czynnościowych.

Równocześnie nie ustawały poszukiwania naturalnych opsyn o zdolnościach hamujących aktywność neuronów. Poszukiwania w świecie bakterii, archebakterii, grzybów i roślin doprowadziły do wyselekcjonowania kilku potencjalnych kandydatów, wśród których dwie pompy protonowe okazały się być bardzo przydatnymi, nowymi narzędziami optogenetyki. Opsynami tymi byly: archaerhodopsin-3 (Arch) z archebkakterii Halorubrum sodomense, o maksymalnej absorpcji światła zielono-żółtego (525-600 nm) i białko Mac/LR/Ops z grzyba Leptosphaeria maculans, o maksymalnej absorpcji również $\mathrm{w}$ widmie zielono-żółtym $(510-570 \mathrm{~nm})$ (CHow i współaut. 2010). Arch okazała się być pompa o pierwszorzędnej kinetyce aktywacji i czasie regeneracji. W neuronalnych hodowlach komórkowych opsyna ta generowała prąd o natężeniu 900pA i hiperpolaryzowała błonę neuronów aż o $76 \mathrm{mV}$. Ponadto wykazywała dobra ekspresje zarówno w błonie ciała komórki, jak i neurytów, nie zmieniajacc przy tym jej podstawowych parametrów elektrycznych. Aktywacja Arch nie powodowała większych zmian $\mathrm{pH}$ cytoplazmy, od tych obserwowanych $\mathrm{w}$ trakcie naturalnej aktywności komórek nerwowych. Ponadto, elektrofizjologiczne pomiary w warunkach in vitro neuronów eksprymujących Arch lub eNpHR wykazały, że pierwsza $z$ nich znacznie silniej hamuje aktywność komórkowa. Arch eksprymowana za pomoca wektorów lentiwirusowych w korze mózgowej myszy hamowała 90\% całkowitej aktywności neuronów w badanym obszarze mózgu. Dodatkowo, nawet jednominutowa, nieprzerwana stymulacja Arch nie powodowała zmian $\mathrm{w}$ podstawowym poziomie aktywności sieci nerwowej po zakończeniu stymulacji. $Z$ kolei eksperymenty in vitro $z$ wykorzystaniem pompy protonowej Mac i pompy chlorowej Halo pozwoliły na dobranie długości fal swiatła stymulujacych selektywnie każda z tych opsyn, odpowiednio $470 \mathrm{~nm}$ i 630 $\mathrm{nm}$. Od tego momentu teoretycznie możliwe stało się jednoczesne, selektywne hamowanie dwóch odrębnych populacji neuronów w mózgu (CHOw i współaut. 2010).

Bardzo dobra kinetyka jaka charakteryzowała się Arch skłoniła naukowców do przeprowadzenia szczegółowych poszukiwań opsyn w rodzaju Halorubrum. W tym celu przetestowano kilka opsyn podobnych sekwencja pompie Arch. Testowane opsyny należały do różnych gatunków i szczepów rodzaju Halorubrum pochodzacych z Tybetu, Australii i innych rejonów świata (HAN i współaut. 2011). Jedna $z$ testowanych opsyn wykazywała niespotykana wcześniej wrażliwość na stymulację światłem. Przy naświetlaniu światłem o długości fali ok. $575 \mathrm{~nm}$ i niewielkiej mocy $\left(7,8 \mathrm{~mW} / \mathrm{mm}^{2}\right)$ generowała ona znacznie większy transbłonowy prąd hiperpolaryzujący neurony niż jakakolwiek wcześniej poznana opsyna. Ta nowo odkryta pompa protonowa pochodziła ze szczepu 
TP009 Halorubrum sp. i została nazwana ArchT. Różni się ona w sekwencji aminokwasowej od Arch w kilku miejscach, ale posiada identyczne spektrum absorbcji światła, kinetyke działania i generuje podobny maksymalny prad transbłonowy (900 pA). ArchT jest jednak ponad trzy razy bardziej czuła na światło niż Arch. Czułość ta manifestuje się głównie w zakresie stymulacji świetlnej o mocy 1-10 $\mathrm{mW} / \mathrm{mm}^{2}$. Matematyczne modele szacuja, że dzięki tak zwiększonej czułości ArchT, możliwe jest hamowanie, za pomoca pojedynczego światłowodu, ponad dwukrotne większej objętości tkanki mózgowej w stosunku do Arch. Aby to potwierdzić, podano lentiwirusy kodujące ArchT do kory makaków królewskich (Macaca mulatta). Wyniki badań pokazały, że ArchT wykazuje dobra ekspresję w neuronach korowych, a same komórki w preparatach histologicznych nie przejawiaja patologii. Badania elektrofizjologiczne pokazały dodatkowo, że ArchT skutecznie hamuje komórki kory w żywym, świadomym zwierzęciu. W trakcie eksperymentu zarejestrowano 74 pojedyncze komórki; u 45-ciu $z$ nich świetlna stymulacja ArchT prowadziła do obniżenia ich częstotliwości wyładowań o 80-100\%. Pozytywny wynik powyższych doświadczeń sygnalizuje potencjalne możliwości w wykorzystaniu optogenetyki w badaniach klinicznych i zastapienia ta metoda $\mathrm{np}$. terapii $\mathrm{z}$ użyciem głębokiej stymulacji mózgu (ang. deep brain stimulation, DBS), stosowanej najczęściej w leczeniu parkinsonizmu, ale czasem także w ostrych i opornych na leczenie farmakologiczne zaburzeniach obsesyjno-kompulsyjnych i depresjach (HAN i współaut. 2011).

Oprócz opsyn pochodzacych od prostych organizmów, jak algi czy archebakterie, starano się również wykorzystać opsyny młodsze ewolucyjnie, np. pochodzace od ssaków rodopsyny będace receptorami GPCR, jak wcześniej wspomniana szczurza rodopsyna 4. Precyzyjna stymulacja światłem opsyn, będących receptorami działajacymi za pośrednictwem różnych białek G i oddziaływujaccych na rozmaitego typu szlaki sygnałowe, wydawała się kuszącym konceptem. Tak zrodziła się technika optoXR. Polega ona na podstawieniu wewnątrzkomórkowych fragmentów 7-transbłonowych pętli rodopsyny wraz $z$ jej C-końcem analogicznymi sekwencjami aminokwasowymi pochodzacymi $z$ receptorów GPCR nie będacych opsynami (AIRAN i współaut. 2009). W ten sposób udało się stworzyć hybrydy białkowe, w których część receptorowa jednego peptydu (rodopsyny) łączono $z$ częścią efektorowa peptydów wiążących różne białka G. Tak skonstruowano dwie hybrydy bydlęcej rodopsyny (normalnie działajacej za pośrednictwem białka $G_{t}$ ): pierwsza $z$ ludzkim receptorem adrenergicznym $a_{1}$ sprzężonym $z$ białkiem $G_{q}$ $i$ druga, $z$ chomiczym receptorem adrenergicznym $\beta_{2}$ sprzężonym $z$ białkiem $G_{s}$. Stymulacja zielonym swiatłem tych receptorów w hodowli komórkowej ludzkich embrionalnych komórek nerek (ang. human embryonic kidney cells, HEK cells), prowadziła do wzrostu stężenia w tych komórkach (odpowiednich względem białka $\mathrm{G}$ ) wtórnych przekaźników sygnałowych lub produktów ich rozpadu: $\mathrm{Ca}^{2+}$, cAMP czy $\mathrm{IP}_{1}$ (monofosforan inozytolu). Również po wystawieniu na 10cio minutowa stymulację świetlna skrawków mózgowych pochodzących od myszy, którym do mózgów podano wektory lentiwirusowe kodujace receptory optoXR, zaobserwowano w tkance wzrost przekaźnika dalszego rzę$\mathrm{du}$, łaczącego szlak sygnałowy cAMP i $\mathrm{Ca}^{2+}$ - ufosforylowanej formy czynnika transkrypcyjnego CREB. Ponadto, eksprymujac te receptory w jądrze półleżącym myszy, można było za pomoca światłowodu wprowadzonego do mózgu regulować aktywność neuronów tej struktury. Jądro półleżące jest częścią układu nagrody w mózgu, motywujaccym zachowanie zwierzat. Podajac do tej struktury wektor kodujacy receptor optoXR złożony $z$ ludzkiego receptora adrenergicznego $\mathrm{a}_{1}$ udało się zrealizować optogenetyczne warunkowanie preferencji miejsca $u$ myszy (AIRAN i współaut. 2009). Było to możliwe przez optyczna stymulację komórek jądra półleżącego zawsze wtedy, gdy zwierzę znajdowało się w wybranej części klatki.

\section{NIE TYLKO OPSYNY}

Wraz $z$ rozwojem molekularnym optogenetyki, rozwijały się również jej techniczne aspekty dotyczace metod dostarczania światła do/z mózgu (kontroli impulsów światła, jednoczesnej stymulacji oraz podglądu aktywności w okolicy sondy) i pomiaru aktywności elektrycznej komórek. Jednocześnie pracowano nad stworzeniem nowych metod filtrowania, obróbki i matematycznej analizy otrzymanego sygnału. W 2007 r., niecałe dwa lata od chwili udanej próby stymulacji komórek nerwowych za pomoca ChR2, zespół Karla Daisseroth'a opublikował pierwsze techniczne rozwiazanie dostarczenia światła do mózgu żywego ssaka, pierwszy "optyczny interfejs neuronalny” (ang. optical neural interface, ONI) (ARAVANIS i współaut. 2007). Autorzy poddali szczura kraniotomii - wywiercili milimetrowej średnicy otwór w jego czaszce i wprowadzili przezeń metalowa kaniule do pierwszorzędowej kory ruchowej wibrys. Kaniula ta najpierw posłużyła do podania wektora lentiwirusowego kodującego ChR2 (pod promotorem kinazy II a zależnej 
od $\mathrm{Ca}^{2+}$, umożliwiającej ekspresję tylko w pobudzajacych neuronach kory), a nastepnie do wprowadzenia światłowodu o średnicy ok. $200 \mu \mathrm{m}$. Światłowód był podłaczony do lasera generujacego światło o długości fali $473 \mathrm{~nm}$. Dwa tygodnie po operacji unieruchamiano i podłączano zwierzę do aparatury eksperymentalnej. Stymulując komórki kory ruchowej 20 sekundowymi pulsami niebieskiego światła Aravanisowi i jego współpracownikom udało się wywoływać ruchy wąsów. Powyższy eksperyment $z$ powodzeniem został powtórzony również na myszach. Od tego momentu stała się możliwa optogenetyczna manipulacja aktywnościa neuronów w żywych, przytomnych ssakach. Eksperyment ten udowodnił również, że światło dostarczone do mózgu nie tylko aktywuje neurony $z$ ChR2, ale także transsynaptycznie rekrutuje dalsze neurony ścieżki ruchowej, w tym przypadku, nerw wzgórzowy, a dalej nerw czaszkowy, który unerwia mięśnie odpowiedzialne za ruch wibrys.

W kolejnym eksperymencie $z$ wykorzystaniem ONI udało się manipulować aktywnością komórek oreksynowych (hipokretynowych) w mysim podwzgórzu (ADAMANTIDIs i współaut. 2007). Komórki wytwarzające neuropeptyd oreksynę biora udział $\mathrm{w}$ regulacji stanu pobudzenia, a utrata ich funkcji związana jest $z$ narkolepsją. Aby kontrolować wybiórczo aktywność komórek oreksynowych podano myszom do podwzgórza wektor lentiwirusowy kodujaccy ChR2 pod promotorem genu oreksyny. Pobudzajac komórki oreksynowe za pomoca pulsów światła o częstotliwości 5-30 Hz lub światłem ciagłym, można było zmniejszać czas wybudzania się myszy $z$ fazy snu wolnofalowgo lub $z$ fazy snu REM (ang. rapid eye movement) w trakcie pojedynczego cyklu snu trwajacego normalnie u myszy ok. 2-3 minut. Podczas tego eksperymentu, gryzonie nie były unieruchamiane i mogły się $w$ miare swobodnie poruszać po klatce - miały przytwierdzony do głowy światłowód i kable odprowadzające sygnał $z$ elektrod EEG (elektroencefalografia) i EMG (elektromiografia). Eksperyment ten był pierwszym, w którym optogenetycznie kontrolowano zachowanie swobodnie poruszajacych się ssaków. Doświadczenie to udowodniło również zależność pomiędzy częstotliwościa aktywności komórek nerwowych a zachowaniem zwierzęcia, gdyż stymulacja komórek oreksynowych o częstotliwości $1 \mathrm{~Hz}$ nie skracała czasu wybudzania się myszy.

Niedługo po powstaniu ONI zaczęto integrować światłowody do stymulacji światłem $z$ elektrodami rejestrujacymi aktywność elektryczna manipulowanych komórek. Przydatność tego systemu została ugruntowana w badaniach nad parkinsonizmem. Jedna $z$ metod leczenia parkinsonizmu jest głeboka stymulacja mózgu, polegajaca na elektrycznej stymulacji jądra niskowzgórzowego lub gałki bladej przyśrodkowej za pomoca elektrody wprowadzonej na stałe do mózgu pacjenta (OKUN 2012). Metoda ta jest obecnie szeroko stosowana, przynoszac dziesiatkom tysięcy osób na całym świecie poprawę stanu zdrowia. Jednak nie wszyscy pacjenci dobrze reaguja na DBS. Sam mechanizm stojacy za pozytywnym skutkiem tej metody leczenia nie jest $\mathrm{w}$ pełni poznany. $Z$ tego względu nieustannie prowadzone sa prace majace na celu zidentyfikowanie tych obwodów i struktur w mózgu, których aktywność jest zmieniona $\mathrm{w}$ chorobie Parkinsona. Optogenetyczna manipulacja, wspólnie $z$ jednoczesna rejestracja elektryczna stymulowanego miejsca, stanowi cenne narzędzie w badaniach na modelach zwierzęcych. Przy wykorzystaniu tego systemu udało się odkryć, że to stymulacja włókien, które unerwiaja jądro niskowzgórzowe, a nie stymulacja komórek tej struktury jest prawdopodobnie odpowiedzialna za pozytywny efekt DBS u myszy. Co więcej, optogenetyczna stymulacja o częstotliwości $130 \mathrm{~Hz}$ warstwy V pierwszorzędowej kory ruchowej, która wysyła projekcje do jacdra niskowzgórzowego, pozwoliła na znaczne zmniejszenie objawów chemicznie wywołanego parkinsonizmu u myszy (GRADINARU i współaut. 2009).

Równocześnie $\quad z$ próbami technicznymi metod dostarczania światła do mózgu, szły starania w kierunku stworzenia transgenicznych linii myszy, które eksprymowałyby różne opsyny w określonej populacji neuronów. Początkowo starania te zaowocowały powstaniem kilku genetycznie zmodyfikowanych linii myszy (Thy1-ChR2-YFP), które eksprymowały ChR2 skoniugowana $z$ białkiem żółtej fluorescencji (ang. yellow fluorescent protein, YFP) pod promotorem Thy 1 (WANG i współaut. 2007). Każda $z$ tych linii miała wyznakowane markerem YFP różne typy komórek, w różnych strukturach mózgu; promotor Thy1 nie umożliwia ekspresji w ściśle ograniczonej, wybranej populacji neuronów. ChR2 w neuronach tych transgenicznych myszy wykazywała dobra, silna ekspresję w błonie cytoplazmatycznej i umożliwiała skuteczna stymulację komórek z częstotliwością sięgajaca $30 \mathrm{~Hz}$. Rejestrując aktywność elektrofizjologiczna pojedynczych komórek w mysich skrawkach mózgowych i stosujac jednocześnie laserowa stymulacje punktowa różnych miejsc tego skrawka udało się zmapować wejścia synaptyczne do komórek piramidalnych i interneuronów w $\mathrm{V}$ i VI warstwie mysiej kory. Użyteczność myszy Thy1-ChR2-YFP została również wykazana w doświadczeniach in vivo. Linia ta posłuży- 
ła do badania połaczeń nerwowych między opuszkami węchowymi a kora gruszkowatą, odpowiedzialną za przetwarzanie bodźców węchowych w mózgu (ARENKIEL i współaut. 2007). Rejestrujac wyładowania jednej z komórek kory gruszkowatej i jednocześnie stymulując światłem powierzchnię opuszki węchowej możliwe było pośrednie zbadanie siły połączeń pomiędzy komórkami mitralnymi znajdującymi się w opuszce węchowej a komórkami kory gruszkowatej. Stymulacja światłem większej powierzchni opuszki węchowej (czyli większej liczby komórek mitralnych) była niezbędna do wzrostu częstotliwości wyładowań potencjałów czynnościowych w komórce kory gruszkowatej.

Nieco później powstała pierwsza linia myszy eksprymujacych hamujacca opsynę w neuronach mózgu, Thy1-NpHR-YFP (ZHAO i współaut. 2008). Aktywność komórek eksprymujaccych NpHR można było hamować za pomoca żółtego światła tak, jak aktywność komórek transfekowanych wirusem we wczesniejszych eksperymentach przeprowadzanych na hodowlach komórkowych. Niestety neurony zawierajace opsyne u tej linii ujawniały takie same wewnątrz-cytoplazmatyczne agregaty białka NpHR, jak komórki w hodowli czy w mózgu myszy poddanych transfekcji wirusem kodujacym tę opsynę.

Aby kontrolować wybrane populacje specyficznych grup komórek posiłkowano się również mysimi liniami Cre (ang. causes recombination) wraz ze specjalnie zaprojektowanymi wektorami adenowirusowymi. Mysie linie Cre bazuja na systemie Cre-loxP (Ryc. 1) który służy do rekombinacji DNA ssaków i innych zwierząt. System ten ma wiele wariantów. Jeden $z$ najczęstszych, składa się $z$ dwóch niezależnie działających elementów. Pierwszym $z$ nich jest rekombinaza Cre pochodzaca od bakteriofaga P1. DNA kodujące ten enzym wraz $z$ wybranym promotorem wprowadza się metodami inżynierii genetycznej do linii komórkowej lub linii zwierzęcej. Drugim elementem systemu jest fragment DNA składajacy się $z$ promotora, kodonu stop oflankowanego $z$ obydwu stron przez krótkie, liczace 34 pary zasad, motywy loxP i na końcu, $z$ właściwego genu. Ten drugi element jest wprowadzany do wektorów wirusowych lub do drugiej linii zwierzęcej. Rekombinaza Cre rozpoznaje motywy loxP i wycina oflankowany przez nie fragment DNA (SAUER 1998). W ten sposób krzyżując np. homozygotyczną linię myszy PV-Cre, której wszystkie komórki parwalbuminowe eksprymuja rekombinazę Cre, z druga homozygotyczna linią myszy Ai32, w której genomie znajduje się sekwencja DNA z promotorem, kodonem stop oflankowanym motywami loxP i genem kodujacym białko

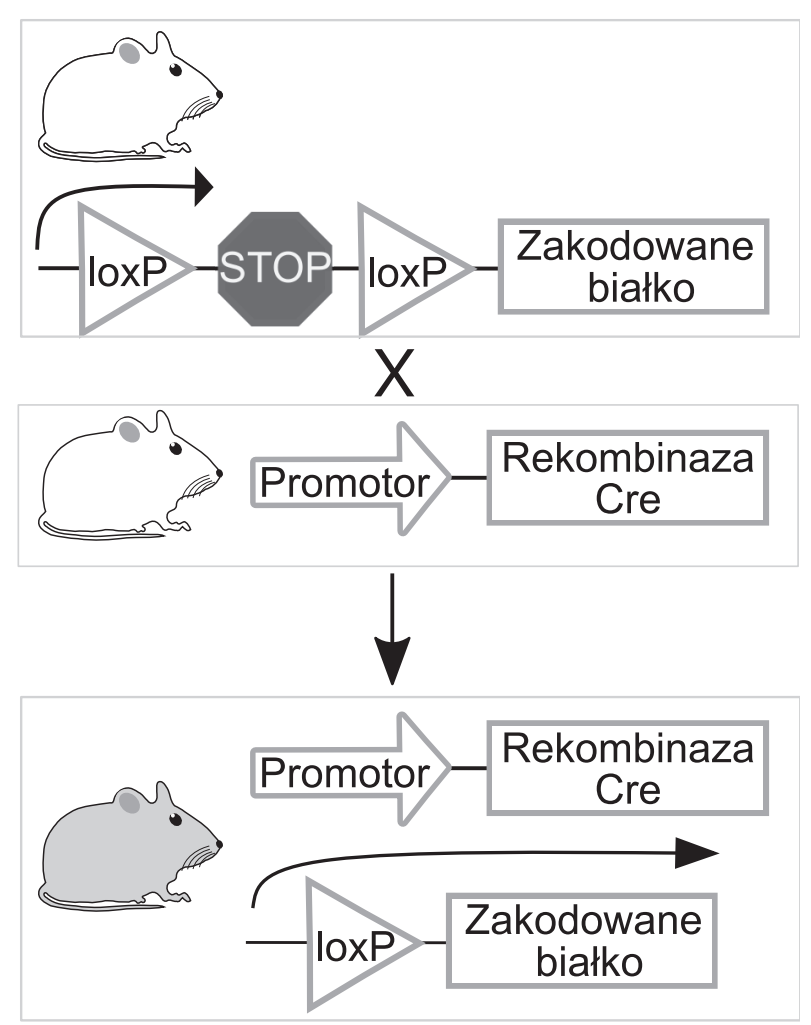

Ryc. 1. Schemat działania systemu Cre-loxP u myszy. (Szczegółowy opis w tekście.)

ChR2-EYFP (ang. enhanced YFP), otrzymujemy potomstwo eksprymujace białko ChR2-EYFP we wszystkich komórkach parwalbuminowych. Obecnie dostępne sa dziesiątki mysich linii, które eksprymuja rekombinazę Cre pod różnymi promotorami oraz wiele linii, które maja wprowadzone do genomu fragmenty DNA, których ekspresja zależna jest od rekombinazy Cre (Mouse Mutant Resource Website, The Jackson Laboratory, Bar Harbor, Maine. World Wide Web https://www.jax.org/research-and-faculty/ resources / cre-repository / characterized-crelines-jax-cre-resource (2019.11.11.)

W początkowych latach istnienia optogenetyki nie było oczywiście żadnych dostępnych linii myszy posiadających DNA kodujące opsyny, których ekpspresja zależna byłaby od obecności białka Cre w komórkach. Takie linie należało dopiero stworzyć. $Z$ uwagi na fakt, że jest to przedsięwzięcie bardzo pracochłonne, drogie i nie zawsze kończące się pełnym sukcesem, początkowo korzystano $z$ wektorów wirusowych zależnych od Cre rekombinazy, których produkcja jest znacznie prostsza i szybsza. Wektory takie bazuja również na systemie Cre-loxP i koduja geny, których ekspresja ujawnia się tylko w komórkach eksprymujacych białko Cre. Dzięki tej technice stworzono pierwsze 
wektory adenowirusowe kodujace ChR2, której ekspresja zależna jest od obecności enzymu rekombinazy w komórce. Na przykład, podajacc takie wirusy do kory myszy eksprymujacej rekombinazę Cre pod promotorem parwalbuminy, można było doprowadzić do zlokalizowanej (w rejonie podania wirusa) ekspresji ChR2 tylko w neuronach parwalbuminowych (KUHLMAN i HUANG 2008).

Jednym $z$ pierwszych przykładów zastosowania adenowirusa kodujacego ChR2, której eksprymacja zależy od obecności rekombinazy Cre, jest doświadczenie badajace polączenia pomiędzy dwoma jądrami podwzgórza. Wirus ten został podany myszom dwóch różnych linii: Pomc-Cre i Agrp-Cre (ATASOY i współaut. 2008). Myszy tych linii eksprymuja rekombinaze Cre pod promotorami genów Pomc i Agrp, których ekspresja charakterystyczna jest dla dwóch różnych populacji komórek GABAergicznych w jąrze łukowatym podwzgórza. Obydwie populacje komórek wysyłaja projekcje do jadra przykomorowego podwzgórza, natomiast pełnia przeciwstawna funkcję. Komórki Pomc sa odpowiedzialne za hamowanie pobierania pokarmu, natomiast komórki Agrp stymuluja jego pobieranie. Po podaniu myszom wirusa do jądra łukowatego podwzgórza, przygotowano żywe skrawki mózgowe zawierające jądro przykomorowe i przeprowadzono rejestracje elektrofizjologiczne $z$ jego pojedynczych neuronów. W trakcie rejestracji komórek jądra przykomorowego jednocześnie stymulowano punktowo różne fragmenty skrawka laserem, aby aktywować aksony komórek Pomc lub Agrp. Pozwoliło to na opis map wejść synaptycznych pochodzacych od komórek Pomc i Agrp do komórek jadra przykomorowego, a także na zbadanie siły tych połączeń.

Wirusy kodujace DNA, którego ekspresja zależna jest od rekombinazy Cre, pozwalaja na zlokalizowana, specyficzna ekspresje opsyn i innych białek w określonych strukturach mózgu. Wirusy tego typu stanowia często niebywale cenne narzędzie w śledzeniu projekcji nerwowych, aktywności komórek i zmian plastycznych zachodzacych podczas rozwoju osobniczego i uczenia się. Czasami jednak w badaniach neurobiologicznych pożąana jest ekspresja, która dotyczy pewnej wybranej populacji komórek w całym mózgu, a nie tylko w jednej, niewielkiej jego strukturze. Kiedy nie zależy nam na zlokalizowanej ekspresji danego białka w mózgu, praca na myszach eksprymujących od urodzenia dane białko w określonym typie komórek w całym mózgu może okazać się łatwiejsza i wygodniejsza. Nie jest wtedy wymagane podawanie wirusa i oczekiwanie na efektywna eksprymacje danej opsyny (eksperymentalnie stwierdzono, że taki czas oczekiwania powinien wynosić od dwóch do trzech tygodni). Również operacje i podawanie wirusów bardzo młodym, np. kilkudniowym zwierzętom jest bardzo trudne, wymaga dużego doświadczenia i wiąże się $\mathrm{z}$ wysokim ryzykiem śmierci zwierzat. Dlatego, kiedy w danym doświadczeniu nie jest wymagana zlokalizowana ekspresja transgenu w mózgu, wygodniejsza jest praca ze zwierzętami transgenicznymi, które od urodzenia posiadaja ekspresje wybranego genu pod wybranym promotorem. W poczatkach istnienia optogenetyki takie rozwiazanie było bardzo ograniczone. Istniało tylko kilka mysich linii transgenicznych eksprymujacych opsyny i ekspresja ta nie zależała od rekombinazy Cre. Ograniczało to w stosunkowo dużym stopniu wykorzystanie tych linii w badaniach nad układem nerwowym. Dopiero rok 2012 przyniósł prawdziwa rewolucję w wykorzystaniu optogenetycznych narzędzi kontroli aktywności komórek nerwowych. Wtedy to powstały linie myszy eksprymujacych zależnie od obecności rekombinazy opsyny: ChR2, eNpHR3.0 i Arch (MADISEN i współaut. 2012). Linie te można krzyżować dowolnie $\mathrm{z}$ dziesiątkami już dostępnych mysich linii Cre. To umożliwia ekspresję tych trzech opsyn w szerokiej gamie komórek w całym organizmie. Linie myszy transgenicznych zostały udostępnione światowej społeczności naukowej (np. depozytorium The Jackson Laboratory), co zaowocowało niebywałym przyśpieszeniem badań neurobiologicznych i rozpowszechniło wykorzystanie samej optogenetyki (por. wzrost liczby prac publikowanych każdego roku poświęconych rozwojowi optogenetyki; DEISSEROTH 2015).

Dzięki powszechnej dostępności, powyższe linie transgeniczne sa obecnie wykorzystywane w setkach laboratoriów na całym świecie, w pracy nad tysiącami różnego typu badań poświęconych układowi nerwowemu. Również w Instytucie Biologii Doświadczalnej im. Marcelego Nenckiego PAN wykorzystujemy w swojej codziennej pracy transgeniczne linie myszy, których DNA koduje opsyny zależne od rekombinazy Cre (Ryc. 2).

Stymulację optogenetyczna łączy się nie tylko $z$ technikami elektrofizjologicznymi, ale także $z$ metodami obrazowania fluorescencyjnego. Połączenie stymulacji optogenetycznej $z$ obrazowaniem przy pomocy genetycznie kodowanych sond wapniowych (ang. genetically encoded calcium indicators, GECIs) i mikroskopia dwufotonowa przyniosło niespotykane wcześniej możliwości badania aktywności całych populacji komórek w mózgu. GECIs sa to specjalnie zaprojektowane białka posiadajace część fluorescencyjna i część umożliwiająca wiązanie jonów wapnia. Zwiazanie wapnia powoduje zmiany konforma- 


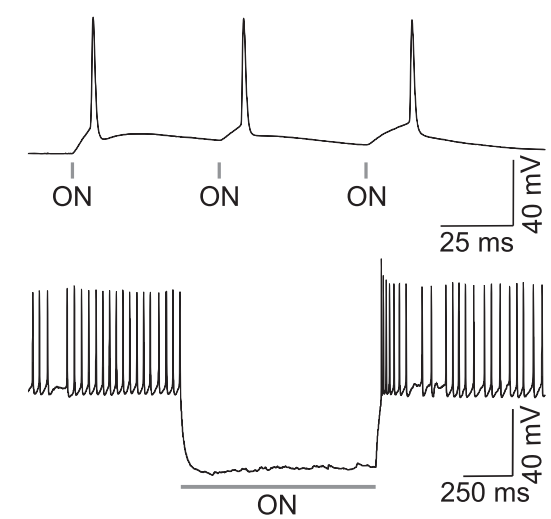

Ryc. 2. Rejestracja aktywności elektrofizjologicznej pojedynczych neuronów korowych w skrawkach mózgowych uzyskanych $z$ myszy eksprymujacych opsyny: aktywująca - ChR2 (góra) lub hamujacca Arch (dół). Stymulacja ChR2 światłem niebieskim (szare pionowe prażki, ON, czas trwania stymulacji 0,5 ms) wywołuje potencjały czynnościowe, natomiast stymulacja Arch światłem żółtym (szary poziomy prązek, ON, 1s) hiperpolaryzuje błonę neuronu i zahamowuje spontanicznie pojawiajace się potencjały czynnościowe. Rejestracje wykonane w Instytucie Biologii Doświadczalnej PAN.

cyjne wpływajace na właściwości fluorescencyjne całego białka, co pozwala rejestrować sygnały wapniowe w postaci światła fluorescencyjnego (GAZDA i współaut. 2017). Jony wapnia są ważnym, wtórnym przekaźnikiem sygnałów komórkowych. W czasie trwania potencjałów czynnościowych, jak i potencjałów synaptycznych jony wapnia dostają się do wnętrza komórki. Stężenie wolnych jonów wapnia w cytoplazmie komórkowej może być więc wykorzystane jako wskaźnik liczby potencjałów czynnościowych, częstotliwości wyładowań czy względnej liczby wejść synaptycznych (YASUDA i współaut. 2004). Połaczenie optogenetyki, mikroskopii dwufotonowej i GECIs umożliwiło po raz pierwszy manipulację działaniem pojedynczego neuronu, z jednoczesnym obrazowaniem aktywności kilkudziesięciu komórek nerwowych, w przytomnym zwierzęciu, wykonującym wyuczone zadanie (RICKGAUER i współaut. 2014). W tym celu, transgenicznym myszom eksprymujacym wskaźnik wapnia GCaMP3 podano do pola CA1 hipokampa wirus kodujacy opsynę C1V1. Opsyna C1V1 jest chimera opsyny ChR1 i VChR1 specjalnie zaprojektowana tak, aby mogła być wykorzystywana w mikroskopii dwufotonowej - jej maksymalna absorpcja przypada na światło podczerwone o długości fali ok. $1040 \mathrm{~nm}$ (PRAKASH i współaut 2012). Jednak, aby rozdzielić jak najlepiej sygnał stymulacji i odczytu, C1V1 była wzbudzana fala o długości $1064 \mathrm{~nm}$, a sonda wapniowa fala o długości $920 \mathrm{~nm}$ (Rickgauer i współaut. 2014). Podczas ope- racji podawania wirusa, montowano również specjalne przezroczyste okno w czaszce myszy, aby można było później obrazować komórki hipokampa. Następnie głowę myszy mocowano do aparatury doświadczalnej tak, aby jej łapki dotykały bieżni. Przed jej pyszczkiem znajdował się ekran wyświetlajacy wirtualny, liniowy labirynt, na którego końcu mysz dostawała nagrodę w postaci kropli wody. W trakcie wykonywania zadania obrazowano aktywność komórek piramidalnych hipokampa, które pełnia funkcje tzw. komórek miejsca (ang. place cells). Komórki te koduja pamięć przestrzenną w mózgu; ich wyładowania ściśle koreluja $z$ miejscem w przestrzeni, w którym zwierzę aktualnie przebywa. Kiedy zmapowano już takie „pola recepcyjne" każdej z obrazowanych komórek, zaczęto stymulować jedną $z$ nich $(1064 \mathrm{~nm})$, jednocześnie obrazując $(920 \mathrm{~nm})$ aktywność wszystkich komórek piramidalnych w polu widzenia. Okazało się, że stymulacja komórki w obszarze labiryntu poprzedzajaccym miejsce, w którym się ona naturalnie wyładowuje, prowadzi do osłabienia lub nawet braku aktywności tej komórki w jej naturalnym polu recepcyjnym. Dodatkowo, manipulacja ta wpływała w podobny sposób również na niewielką część innych, nie stymulowanych neuronów. Doświadczenie to pokazało, że możliwe jest skuteczne manipulowanie pojedyncza komórka nerwowa w przytomnym zwierzęciu wykonujacym zadanie behawioralne. Ponadto sugeruje ono, że interakcje pomiędzy komórkami miejsca w lokalnej sieci moga mieć funkcjonalne znaczenie w kształtowaniu ich pól recepcyjnych. Chociaż połączenie GECIs i optogenetyki daje olbrzymie możliwości w badaniu sieci nerwowych mózgu, to niestety kinetyka tych wskaźników jest za wolna, aby rzetelnie odzwierciedlać pojedyncze potencjały czynnościowe in vivo. Wykorzystanie GECIs w doświadczeniach in vivo nie umożliwia precyzyjnego badania właściwości pojedynczych potencjałów czynnościowych i rejestracji ciagu wyładowań w szybko wyładowujacych się interneuronach parwalbumionwych. Nie jest możliwe także badanie podprogowej i dendrytycznej aktywności elektrycznej w komórkach nerwowych in vivo, ze względu na nieczułość sensorów wapniowych na hiperpolaryzację i zakłócajacy rejestrację napływ jonów wapnia przez synapsy.

Powyższe problemy moga być częściowo rozwiazane przez użycie genetycznie kodowanych sond napięcia (ang. genetically encoded voltage indicators, GEVIs), które maja szybsza kinetykę i znacznie większa czułość niż sondy wapniowe. GEVIs w warunkach in vitro umożliwiaja badanie pojedynczych potencjałów czynnościowych i aktywności pod- 
progowej komórek nerwowych. Sondy te sa genetycznie zaprojektowanymi białkami posiadającymi domenę wrażliwa na zmiany napięcia (ang. voltage-sensitive domain) i część będaca fluoroforem. Badania na wywilżnach $\mathrm{i}$ myszach in vivo, $\mathrm{z}$ jednoczesna rejestracja optyczna i elektrofizjologiczna wykazały, że fluorescencyjny sygnał nowych GEVIs perfekcyjnie pokrywa się $z$ sygnałem elektrycznym. W rejestracjach tych, sygnał fluorescencyjny odzwierciedlajacy pojedyncze potencjały czynnościowe był opóźniony względem elektrycznego tylko o 0,24 ms w korze żywych myszy i o 0,19 ms w całkowitych eksplantatach mózgowych wywilżn (GONG i współaut. 2015). Doświadczenia te ujawniły duży potencjał nowych typów GEVIs, umożliwiających badanie aktywności wielu komórek $z$ precyzja pozwalająca na odczyt pojedynczych potencjałów czynnościowych.

\section{NIE TYLKO OPTOGENETYKA}

W przeciagu ostatnich siedmiu lat pojawiły się nowe, bardzo kreatywne i wyrafinowane metody manipulacji aktywnościa komórek nerwowych. Niektóre $z$ nich wykorzystuja częściowo pewne elementy metod optogenetycznych i podobnie jak one, służa do manipulacji potencjałem błony komórkowej. Inne, adaptuja pewne elementy optogenetyki do regulacji czynności komórek na całkowicie odmiennym poziomie fizjologicznej aktywności, związanym $\mathrm{z}$ transkrypcja DNA czy modyfikacją chromatyny. Inne wreszcie, sa całkowicie nowatorskie i wykorzystuja magnetyczne metody stymulacji neuronów. Zgodnie $\mathrm{z}$ chronologia ich powstawania, pierwsza opiszemy technike LITEs (ang. light-inducible transcriptional effectors) (KONERMANN i współaut. 2013).

LITE jest metoda wykorzystujaca pare specjalnie zaprojektowanych hybryd białkowych, które sa zdolne ze soba oddziaływać i dimeryzować. Pierwsza hybryda składa się $z$ domeny TALE, rozpoznającej i wiążącej odpowiednie sekwencje DNA, i z części białka CRY2 (ang. cryptochrome circadian regulator 2), czułego na światło niebieskie. Domena TALE może być modyfikowana, aby rozpoznawać fragmenty łańcucha DNA o wybranej sekwencji. Druga hybryda zbudowana jest $z$ białka CIB1 (ang. calcium and integrin binding 1) i $z$ wybranego białka efektorowego, które pośredniczy w modulacji transkrypcji. CRY2 po wzbudzeniu światłem niebieskim zmienia konformację i jest rozpoznawane przez białko CIB1 - tak powstaje heterodimer składajacy się $z$ dwóch hybryd białkowych (TALE-CRY2:CIB1-efektor). $\mathrm{W}$ stanie nieaktywnym hybryda TALE-CRY2 wiaże region promotorowy docelowego genu, a w tym samym czasie hybryda CIB1-efektor pozostaje niezwiazana $\mathrm{i}$ wolna $\mathrm{w}$ jądrze komórki. System ten można też odwrócić, powstaje wówczas białko CIB1 połączone $z$ domena TALE oraz CRY2 $z$ białkiem efektorowym modulującym transkrypcję. Wykorzystujac sekwencję TALE rozpoznajaca region promotorowy genu Neurog2 (ang. neurogenin 2) i białko efektorowe VP64 będace syntetycznym silnym aktywatorem transkrypcji, stworzono następujace hybrydy: TALE (Neurog2)-CRY2 i CIB1-VP64. Wykorzystując powyższa parę białek udało się za pomoca stymulacji świetlnej podnieść poziom ekspresji genu Neurog2 w warunkach in vitro. Różnice $\mathrm{w}$ poziomie ekspresji w stosunku do kontroli były obserwowane już po $30 \mathrm{~min}$ od stymulacji. Po 12 godzinach stymulacji różnica w poziomie ekspresji mRNA Neurog2 była ok. 20 razy wyższa $\mathrm{w}$ stosunku do komórek transfekowanych kontrolnym wirusem kodujacym GFP (ang. green fluorescent protein) zamiast hybryd białkowych (KONERMANN i współaut. 2013).

$\mathrm{W}$ dalszych badaniach $\mathrm{w}$ warunkach in vivo wykorzystano inne hybrydy $\mathrm{z}$ domena TALE rozpoznajaca sekwencję genu Grm2 (ang. glutamate metabotropic receptor 2): TALE(Grm2)-CIB1 i CRY2-VP64. Do mózgu myszy podano dwa wirusy, każdy kodujący jedna $z$ hybryd białkowych, i wprowadzono światłowód $\mathrm{w}$ miejsce iniekcji wirusów. Po ośmiu dniach od operacji stymulowano ten obszar mózgu pulsami światła przez 12 godzin. Po tym czasie sprawdzono poziom ekspresji mRNA genu Grm2. Ekspresja ta okazała się ponad dwa razy wyższa w stosunku do poziomu notowanego u zwierzat niestymulowanych. W neuronach hodowli komórkowej udało się za pomoca światła zmniejszyć około dwukrotnie poziom ekspresji genu Grm2 wykorzystując sztuczna domenę represorowa SID4X, pośrednicząca w deacetylacji histonów, a przyłączona do CRY2. Niemalże dwukrotnie został zmniejszony również poziom acetylacji histonu H3K9 przy promotorze genu Grm2. Metoda LITEs udowodniła, że za pomoca światła możliwa jest bezpośrednia regulacja aktywności genów i modyfikacja chromatyny (KONERMANN i współaut. 2013).

Druga metoda wykorzystuje magneto-termiczna stymulację komórek (CHEN i współaut. 2015). Stosuje się w niej magnetyczne, sferyczne nanocząsteczki o średnicy $22 \mathrm{~nm}$. Zbudowane sa one $z$ tlenku żelaza (II) diżelaza (III) - $\mathrm{Fe}_{3} \mathrm{O}_{4}$ i powleczone sa poli(tlenkiem etylu) dla lepszej stabilności koloidalnej i biokompatybilności. Nanocząstki te, po wzbudzeniu silnym polem magnetycznym i namagnesowaniu, oddaja ciepło. Drugim elementem układu jest receptor TRPV1 bę- 
dący kanałem kationowym reagującym na wzrost temperatury w organizmie - znacznie zwiększa swoją przewodność przy temperaturze powyżej $43^{\circ} \mathrm{C}$. Twórcy tej metody, aby sprawdzić jej skuteczność, poddali linie komórkowe HEK transfekcji wektorami lentiwirusowymi kodujaccymi TRPV1 i sondę wapniowa GCaMP6s. Po wzbudzeniu nanoczasstek polem magnetycznym obserwowano fluorescencyjny sygnał wapniowy odzwierciedlający aktywność elektryczną komórek. Stymulacja ta udała się również w hodowli komórek hipokampalnych utrzymywanych w medium zawierajacym magnetyczne nanoczastki. Neurony te pod wpływem pola magnetycznego synchronicznie odpowiadały seria wyładowań. Powyższe odpowiedzi miały 5-sekundowa latencję w stosunku do stymulującego bodźca magnetycznego, co ujawnia, że metoda ta ma znacznie wolniejszą kinetykę w stosunku do optogenetyki. Skuteczność tej metody pokazano również in vivo. Najpierw podano myszom wirus kodujacy TRPV1 do pola brzusznego nakrywki (ang. ventral tegmental area). Po czterech tygodniach przeprowadzono nastepna operację, podając magnetyczne nanocząsteczki w miejsce wcześniejszej iniekcji wirusem. Następnie uśpione myszy przez 20 min były wystawione na 10-sekundowe pulsy pola magnetycznego. Okazało się, że po poddaniu zwierzat magnetycznej stymulacji widoczny jest znaczacy wzrost liczby aktywnych komórek w polu brzusznym nakrywki. Aktywność neuronów została zbadana metoda immunohistochemiczna, w której wykrywano obecność białka c-Fos, produktu genu wczesnej odpowiedzi (c-fos). Uznaje się, że c-Fos jest wyznacznikiem zwiększonej aktywności neuronalnej. Eksperyment ten powtórzono również na myszach, którym nanocząstki podano miesiac przed magnetyczna stymulacją. W tym przypadku także obserwowano zwiększona liczbę komórek $z$ białkiem c-Fos, co dowodzi, że podane nanocząstki długo pozostaja w organizmie i za ich pomoca możliwa jest chroniczna stymulacja komórek w mózgu. Ponadto, nie zaobserwowano żadnych różnic w gęstości komórek nerwowych czy glejowych pomiędzy mózgami zwierząt poddanych magnetycznej stymulacji i zwierzat nie stymulowanych (CHEN i współaut. 2015). Metoda ta więc wydaje się być bezpieczna.

Trzecia metoda wykorzystuje sferyczne nanocząsteczki złota o średnicy 20 nm, które po oświetleniu światłem o długoś $523 \mathrm{~nm}$ wypromieniowuja pochłonięta energię w postaci ciepła. Szybki wzrost temperatury przy błonie komórki prowadzi do chwilowej zmiany jej pojemności elektrycznej, co generuje prąd pojemnościowy, który depolaryzuje błonę neuronalna, prowadzac do wywołania po- tencjału czynnościowego (CARVALHO-DE-SoUZA i współaut. 2015). Depolaryzacja błony komórkowej jest jednak możliwa tylko w przypadku, gdy nanocząstki złota znajdują się w jej bezpośredniej bliskości. Autorzy tej techniki najpierw sprawdzili użyteczność wyprodukowanych nanoczasstek dodając je do roztworu w czasie rejestracji elektrofizjologicznych $z$ neuronów zwoju rdzenia kręgowego szczura $z$ hodowli komórkowej. Przy stężeniu nanoczastek wynoszacym 50 nM, stymulacja $1 \mathrm{~ms}$ pulsami zielonego światła (523 nm) powodowała wyładowania potencjałów czynnościowych w ok. 80\% komórek. Niestety wykorzystane nanoczastki nie łaczyły się $z$ komórkami i były łatwo wypłukiwane przez świeży roztwór. $Z$ tego powodu wykorzystano nanoczastki złota skoniugowane ze streptawidyna i dwa przeciwciała skoniugowane $z$ biotyna. Streptawidyna jest przeciwciałem wiążącym biotynę. Przeciwciała $z$ biotyna były skierowane przeciwko receptorowi TRPV1 i receptorowi $\mathrm{P} 2 \mathrm{X}_{3}$. Oba te receptory występuja w komórkach zwoju rdzeniowego. Noc przed rejestracja, hodowle komórkowe neuronów zwoju rdzeniowego inkubowano $Z$ jednym $z$ przeciwciał. Następnego dnia hodowle były przepłukiwane świeżym buforem, aby wypłukać nie zwiazane $z$ receptorami przeciwciała. Rejestracje elektrofizjologiczne i stymulacja świetlna ujawniły, że po dodaniu do roztworu nanocząstek ze streptawidyna, komórki staja się czułe na światło. Ponadto 20-minutowe płukanie komórek świeżym roztworem nie wypłukiwało nanoczasteczek i nie zmniejszało ich efektywności. $Z$ uwagi na fakt, że biotynylowane przeciwciała sa drogie w użyciu, eksperyment powtórzono ze zwykłymi przeciwciałami i cząsteczkami złota skoniugowanymi $z$ II-rzędowymi przeciwciałami. Efekt był podobny, jak przy próbach ze zmodyfikowanymi przeciwciałami. Możliwa była stymulacja komórek światłem, a nanoczastki złota nie podlegały wypłukaniu (CARVALHO-DE-SOUZA i współaut. 2015). Metoda ta nie wymaga więc żadnej manipulacji genetycznej, a selektywność względem stymulowanych komórek odbywa się na zasadzie doboru specyficznych przeciwciał skierowanych przeciwko białkom błony komórkowej. Metoda ta jest tylko jednokierunkowa i nie umożliwia hamowania aktywności komórek nerwowych. Ponadto, przeciwciała, za pomoca których nanoczasstki sa przytwierdzane do błon komórkowych, moga prawdopodobnie podlegać degradacji w żywym układzie, a nanoczasteczki być usuwane $z$ organizmu. Dlatego dłuższe wykorzystanie ich w żywym organizmie może być zwiazane $z$ koniecznością powtórzonych aplikacji.

Czwarta metoda wykorzystuje specjalne sferyczne nanocząstki o średnicy $90 \mathrm{~nm}$. 
Ich rdzeń zbudowany jest $z$ nanokryształów NaYF4 domieszkowanych jonami $\mathrm{Yb}^{3+} / \mathrm{Tm}^{3+}$ lub $\mathrm{Yb}^{3+} / \mathrm{Er}^{+3}$. Po wzbudzeniu falami w zakresie bliskiej podczerwieni (980 nm) emituja odpowiednio światło niebieskie lub zielone. Swiatło to ma wystarczajaca moc, aby wzbudzić opsyny: ChR2 w przypadku nanoczastek $z \mathrm{Tm}^{3+}$ i Arch w przypadku nanocząstek $z \mathrm{Er}^{+3}$ (CHEN i współaut. 2018). Skuteczność tej metody została sprawdzona w warunkach in vitro $\mathrm{w}$ rejestracjach elektrofizjologicznych na skrawkach $z$ myszy eksprymujacych ChR2, którym podano do mózgu nanocząstki. Pulsy światła podczerwonego wywoływały potencjały czynnościowe w neuronach, ale skuteczność tej stymulacji nie była kompletna, nie każdy puls generował potencjał czynnościowy. Ponadto, kinetyka aktywacji ChR2 przez stymulację nanoczastek światłem podczerwonym była nieco wolniejsza w stosunku do bezpośredniej stymulacji tej opsyny światłem niebieskim. Kolejna fazę eksperymentu przeprowadzono in vivo na myszach (CHEN i współaut. 2018). Zwierzętom eksprymujacym rekombinazę Cre w komórkach dopaminergicznych podano wektor wirusowy kodujacy ChR2, której ekspresja zależna była od Cre rekombinazy. Wirus został podany do pola brzusznego nakrywki, rejonu mózgu leżącego ok. 4,2 mm pod czaszka. Po czterech tygodniach podano w ten sam rejon nanoczasteczki NaYF4: $\mathrm{Yb}^{3+}$ / $\mathrm{Tm}^{3+}$. Stymulacja światłem podczerwonym przez czaszkę myszy aktywowała nanoczasteczki, które emitowały światło, a następnie to światło wzbudzało ChR2 w błonie neuronów i powodowało ich depolaryzację i wyładowania. Efektywność tej metody wydedukowano na podstawie zwiększonej liczby komórek $z$ białkiem c-Fos, w stosunku do zwierząt niestymulowanych. Dzięki zastosowaniu woltamperometrii cyklicznej szybkiej zmiany potencjału (ang. fast scan cyclic voltammetry, FSCV) możliwe było również sprawdzenie ilości dopaminy jaka wydzielaja komórki pola brzusznego nakrywki u myszy stymulowanej przezczaszkowo światłem podczerwonym. Komórki pola brzusznego nakrywki wysyłaja projekcje do brzusznej części prążkowia. Stymulacja dwusekundowymi pulsami światła podczerwonego komórek pola brzusznego nakrywki prowadziła do znacznie zwiększonego poziomu uwalniania dopaminy w brzusznej części prążkowia.

W innych badaniach sprawdzono również efektywność hamowania przez nanocząsteczki NaYF4: $\mathrm{Yb}^{3+} / \mathrm{Er}^{+3}$ (CHEN i współaut. 2018). W tym celu myszom eksprymujacym Cre rekombinaze w neuronach pobudzajacych podano do hipokampa wirus kodujacy Arch, której ekspresja zależna była od rekombinazy. Po czterech tygodniach, uśpionym my- szom podano do hipokampa nanoczastki i dootrzewnowo kwas kainowy. Kwas ten wywołuje niekontrolowana aktywność komórek nerwowych, która tutaj obserwowano jako wzrost liczby neuronów $z$ białkiem c-Fos. Po podaniu kwasu kainowego myszy były stymulowane przezczaszkowo światłem podczerwonym. Następnie sprawdzano ekspresję białka c-Fos w komórkach hipokampa. Liczba komórek hipokampa $z$ białkiem $c-$ -Fos była mniejsza u myszy stymulowanych światłem podczerwonym niż kontrolnych, nie stymulowanych. Dowodzi to skuteczności hamowania aktywności neuronów przy pomocy opsyny Arch aktywowanej światłem emitowanym przez nanoczasteczki. Stosujac te nanocząstki wykazano również ich przydatność w badaniach behawioralnych na myszach. $Z$ wykorzystaniem nanoczastek i przezczaszkowej stymulacji światłem podczerwonym powtórzono eksperyment $z$ optogenetycznym przywoływaniem pamięci (ang. memory recall) u myszy (LiU i współaut 2012). W oryginalnej pracy wykorzystano specjalny system czasowej kontroli ekspresji genów, który umożliwił ekspresję ChR2 w sprecyzowanej populacji komórek hipokampa, które były aktywne w chwili, gdy mysz była poddawana warunkowaniu awersyjnemu. Po warunkowaniu, stymulacja niebieskim światłem w innym kontekście sytuacyjnym prowadziła do zamierania zwierzęcia w bezruchu, co sugeruje przywołanie wspomnień strachu. W oryginalnym doświadczeniu grupy Liu zastosowano do stymulacji światłowód wprowadzony do mózgu myszy. Twórcy nowych nanoczastek powtórzyli ten sam efekt behawioralny stosujac stymulację przezczaszkową światłem podczerwonym (CHEN i współaut. 2018). Dodatkowo udowodniono, że nanoczastki wprowadzone do mózgu myszy pozostaja w nim przez okres co najmniej jednego miesiaca $i$ nie wykazuja cytotoksyczności. Doświadczenia pokazały, że metoda ta ma ogromny potencjał, stanowiąc idealne uzupełnienie standardowego podejścia optogenetycznego, ponieważ jej zastosowanie nie wymaga chronicznej implantacji światłowodów do wnętrza tkanki mózgowej. Ten ogromny walor nowej metody może przyśpieszyć wykorzystanie optogenetyki w medycynie i zastapić np. elektrody do głębokiej stymulacji mózgu.

\section{PODSUMOWANIE}

Nieustający rozwój badań biologicznych odbywa się dzięki rozwojowi nowych narzędzi badawczych pozwalajacych mierzyć i obserwować procesy fizjologiczne w żywych organizmach w sposób wcześniej nieosiagalny. Postęp w dziedzinie mikroskopii optycznej, 
fluorescencyjnej, elektronowej, cytometrii przepływowej, wysokoprzepustowego sekwencjonowania DNA i mnóstwa innych metod specyficznych dla każdej gałęzi biologii i medycyny pozwala przesuwać granice naszych możliwości w badaniu życia na ziemi. Postęp ten odbywa się również dzięki rozwojowi takich nauk jak bioinformatyka, fizyka, matematyka i statystyka, pozwalających na zautomatyzowana analizę ogromnych zasobów danych, projektowanie nowych białek, analize kinetyki ich reakcji czy badanie pokrewieństwa ewolucyjnego. Postęp w badaniach biologicznych odbywa się nie tylko dzięki nowym narzędziom w tych gałęziach nauki, ale także dzięki dokonanym już odkryciom w dziedzinie biologii i wykorzystaniu narzędzi dostarczonych przez sama naturę. Narzędzi takich jak polimeraza DNA, plazmid Ti do transformacji genetycznej roślin, zjawisko interferencji RNA do wyciszania genów czy np. systemy do precyzyjnej modyfikacji genów na bazie białek TALE lub na bazie CRISPR/Cas. Wszystkie te narzędzia stworzyła natura, a człowiek nauczył się je wykorzystywać do własnych celów. Również opsyny i wiele innych białek efektorowych i receptorowych oraz ich ligandy wymienione w niniejszej pracy sa tego przykładem. To właśnie odkrycia narzędzi natury i ich adaptacje do celów naukowych prowadziły w ostatnich stu latach do największych przełomów w dziedzinie biologii. Czy optogenetyka jest takim przełomem? Metoda ta niewatpliwie jest kamieniem milowym w neurobiologii. Umożliwia manipulację aktywnościa komórek nerwowych $\mathrm{z}$ dokładnościa, specyficznościa i kinetyka nieosiagalna dla żadnego $z$ wcześniejszych systemów regulujacych potencjały czynnościowe błony komórkowej. Jest to metoda obecnie szeroko stosowana w badaniach nad układem nerwowym i trudno sobie wyobrazić dzisiejsza neurobiologię w oderwaniu od tej techniki. Optogenetyka umożliwiła badania układu nerwowego, których przeprowadzenie było nie do zrealizowania przed jej powstaniem, takich jak optogenetyczne przywoływanie pamięci czy stymulacja aktywności pojedynczych komórek. Metoda ta była również podstawą i inspiracja innych metod powstałych później: optoXR, LITEs i metod $z$ wykorzystaniem nanoczasteczek. Jednocześnie sama historia rozwoju technik manipulacji aktywnościa komórek nerwowych stanowi cenną lekcję. Uczy, że narzędzia natury moga przyjść nieoczekiwanie $z$ pomoca $\mathrm{W}$ rozwiazaniu pewnych technicznych problemów. Również istota samej optogenetyki i poszukiwania nowych opsyn powinny nas skłonić do refleksji. To dzięki skromnym archebakteriom, algom i grzybom zamieszkujacym bagna, sa- dzawki czy słone jeziora, mamy dzisiaj takie potężne narzędzie jak optogenetyka. Dowodzi to wagi zachowania ekosystemów i ich bioróżnorodności, która w ostatnich latach stała się poważnie zagrożona przez niekontrolowane, wywołane przez człowieka zmiany klimatyczne.

$$
\text { Streszczenie }
$$

Sterowanie czynnością elektryczną wybranych, specyficznych grup komórek nerwowych lub nawet pojedynczej komórki w mózgu pozwala na zrozumienie tego, jak sieci neuronowe przetwarzaja i koduja informacje. Możliwość manipulacji aktywnością neuronów jest niezbędna w badaniu obwodów neuronalnych, ich funkcji i roli w zdrowym i chorym mózgu. Obecnie istnieje wiele metod regulacji aktywności komórek nerwowych wykorzystujących różne podejścia i narzędzia. Techniki te różnią się bardzo pod względem specyficzności komórkowej, kinetyki i kierunku zmiany aktywności komórkowej (aktywacja/hamowanie). W niniejszej pracy wymieniamy różne metody kontrolowania aktywności neuronów poczynając od lat 60. ubiegłego wieku, a kończac na technikach XXI w. Najwięcej miejsca przeznaczamy na opis opsyn i rozwoju metod zastosowania optogenetyki. Oddzielny rozdział poświęcamy charakterystyce metod powstałych w ostatnich latach, które wykorzystuja nanocząsteczki i optyczna manipulację transkrypcja DNA.

\section{LITERATURA}

AdAMANTIDIS A. R., Zhang F., ARAVANiS A. M., DEISSEROTH K., DE LECEA L., 2007. Neural substrates of awakening probed with optogenetic control of hypocretin neurons. Nature 450, 420-424.

Airan R. D., Thompson K. R., Fenno L. E., BerNSTEIN H., DEISSEROTH K., 2009. Temporally precise in vivo control of intracellular signalling. Nature 458, 1025-1029.

Alexander G. M., Rogan S. C., ABbas A. I., ARmbruster B. N., PEI Y., Allen J. A., NONNEMAN R. J., HARTMANN J., MOY S. S., NicOlelis M. A., MCNAMARA J. O., Roth B. L., 2009. Remote control of neuronal activity in transgenic mice expressing evolved $G$ protein-coupled receptors. Neuron 63, 27-39.

Aravanis A. M., Wang L. P., Zhang F., Meltzer L. A., Mogri M. Z., SchneIder M. B., DeISSEROTH K., 2007. An optical neural interface: in vivo control of rodent motor cortex with integrated fiberoptic and optogenetic technology. J. Neural Eng. 4, S143-S156.

ARenkiel B. R., PECA J., DAvison I. G., FEliciano C., Deisseroth K., Augustine G. J., Ehlers M. D., FEnG G., 2007. In vivo light-induced activation of neural circuitry in transgenic mice expressing channelrhodopsin-2. Neuron 54, 205-218

ARmbruster B. N., Li X., Pausch M. H., Herlitze S., ROTH B. L., 2007. Evolving the lock to fit the key to create a family of $G$ protein-coupled 
receptors potently activated by an inert ligand. Proc. Natl. Acad. Sci. USA 104, 5163-5168.

Atasoy D., APONTE Y., Su H. H., SteRnson S. M., 2008. A FLEX switch targets Channelrhodopsin-2 to multiple cell types for imaging and long-range circuit mapping. J. Neurosci. 28, 7025-7030.

BANGHART M., BORgES K., ISACOFF E., TRAUNER D., KRAMER R. H., 2004. Light-activated ion channels for remote control of neuronal firing. Nat. Neurosci. 7, 1381-1386.

BOLLA F., 1877. Contributions to the physiology of vision and of the sensation of colour. Q. J. Microsc. Sci. 17, 226-232.

BOyden E. S., ZHANG F., BAMBerg E., NAGEL G., DEISSEROTH K., 2005. Millisecond-timescale, genetically targeted optical control of neural activity. Nat. Neurosci. 8, 1263-1268.

Brestead J. H., 1930. The Edwin Smith Surgical Papyrus. The University of Chicago Press, Chicago.

Carvalho-De-Souza J. L., Treger J. S., Dang B., Kent S. B., PepPerberg D. R., Bezanilla F., 2015. Photosensitivity of neurons enabled by cell-targeted gold nanoparticles. Neuron 86, 207-217.

Chang J. Y., NAKahata Y., HaYano Y., Yasuda R., 2019. Mechanisms of Ca2+/calmodulin-dependent kinase II activation in single dendritic spines. Nat. Commun. 10, 2784.

Chen R., Romero G., Christiansen M. G., Mohr A., ANIKEEVA P., 2015. Wireless magnetothermal deep brain stimulation. Science 347 , 1477-1480.

Chen S., Weitemier A. Z., Zeng X., He L., Wang X., TAO Y., HUANG A. J. Y., HASHIMOTODANI Y. KANO M., IWASAKI H., PARAJUli L. K., OKABE S., TeH D. B. L., ALl A. H., Tsutsui-KimurA I., TANAKA K. F., LIU X., MCHUGH T. J., 2018. Near-infrared deep brain stimulation via upconversion nanoparticle-mediated optogenetics. Science 359, 679-684.

Chow B. Y., HaN X., Dobry A. S., QIAN X., Chuong A. S., Li M., Henninger M. A., BelFORT G. M., LIN Y., MONAHAN P. E., BOYDEN E. S., 2010. High-performance genetically targetable optical neural silencing by light-driven proton pumps. Nature 463, 98-102.

Dalva M. B., KATZ L. C., 1994. Rearrangements of synaptic connections in visual cortex revealed by laser photostimulation. Science 265, 255-258.

DEISSEROTH K., 2010. Controlling the brain with light. Sci. Am. 303, 48-55.

DEISSEROTH K., 2011. Optogenetics. Nat. Methods. 8, 26-29.

DEISSEROTH K., 2015. Optogenetics: 10 years of microbial opsins in neuroscience. Nat. Neurosci. 18, 1213-1225.

ERnst O. P., SÁNCHEZ Murcia P. A., DAldrop P., TSunOdA S. P., KateriYa S., HegemanN P., 2008. Photoactivation of channelrhodopsin. J. Biol. Chem. 283, 1637-1643.

GazDA K., BAZAEA M., WęGIERSKI T., 2017. Mikroskopowe obrazowanie jonów wapnia za pomoca genetycznie kodowanych sond. Postepy Biochem. 63, 34-43.

Gong Y., Huang C., Li J. Z., Grewe B. F., Zhang Y., EISMANN S., SChNiTZER M. J., 2015. Highspeed recording of neural spikes in awake mice and flies with a fluorescent voltage sensor. Science 350, 1361-1366.

GRADINARU V., THOMPSON K. R., DEISSEROTH K., 2008. eNpHR: a Natronomonas halorhodopsin enhanced for optogenetic applications. Brain Cell Biol. 36, 129-139.
GRAdinaRU V., MOGRI M., THOMPSON K. R., HENDERSON J. M., DEISSEROTH K., 2009. Optical deconstruction of parkinsonian neural circuitry. Science 324, 354-359.

Gradinaru V., Zhang F., Ramakrishnan C., Mattis J., PRAKASH R., Diester I., GOSHEN I., THOMPSON K. R., DEISSEROTH K., 2010. Molecular and cellular approaches for diversifying and extending optogenetics. Cell 141, 154-165.

GUNAYDin L. A., YIZHAR O., BERNDT A., SOHAL V. S., Deisseroth K., HEgEMANN P., 2010. Ultrafast optogenetic control. Nat. Neurosci. 13, 387-392.

HAN X., BOYDEN E. S., 2007. Multiple-color optical activation, silencing, and desynchronization of neural activity, with single-spike temporal resolution. PLoS One 2, e299.

Han X., Chow B. Y., Zhou H., Klapoetke N. C., ChuONG A., RAJIMEHR R., YANG A., BARATTA M. V., Winkle J., Desimone R., BOYdEN E. S., 2011. A high-light sensitivity optical neural silencer: development and application to optogenetic control of non-human primate cortex. Front. Syst. Neurosci. 5, 18.

HORI N., IKEDA K., ROBERTS E., 1979. Muscimol, GABA and picrotoxin: effects on membrane conductance of a crustacean neuron. Brain Res. 141, 364-370.

HUANG F., TANG B., JIANG H., 2013. Optogenetic Investigation of Neuropsychiatric Diseases. Int. J. Neurosci. 123, 7-16.

Hull E. M., 1968. Corticofugal influence in the macaque lateral geniculate nucleus. Vision Res. 8, 1285-1298.

KARPOVA A. Y., TERVO D. G., Gray N. W., SVOBODA K., 2005. Rapid and reversible chemical inactivation of synaptic transmission in genetically targeted neurons. Neuron 48, 727-735.

KITAMOTO T., 2001. Conditional modification of behavior in Drosophila by targeted expression of a temperature-sensitive shibire allele in defined neurons. J. Neurobiol. 47, 81-92.

KonERMANN S., BRIGHAM M. D., TREVINO A., HsU P. D., Heidenreich M., Cong L., Platt R. J., SCOTT D. A., ChURCH G. M., ZHANG F., 2013. Optical control of mammalian endogenous transcription and epigenetic states. Nature 500, 472-476.

KuHLMAN S. J., HuANG Z. J., 2008. High-resolution labeling and functional manipulation of specific neuron types in mouse brain by Cre-activated viral gene expression. PLoS One 3 , e2005.

LeChNer H. A., Lein E. S., Callaway E. M., 2002. A genetic method for selective and quickly reversible silencing of mammalian neurons. J. Neurosci. 22, 5287-5290.

Li X., GuTIERREZ D. V., HANSON M. G., HAN J., MARK M. D., Chiel H., HEgEmann P., LANDMESSER L. T., HeRlitze S., 2005. Fast noninvasive activation and inhibition of neural and network activity by vertebrate rhodopsin and green algae channelrhodopsin. Proc. Natl. Acad. Sci. USA 102, 17816-17821.

LIMA S. Q., MiESENBÖCK G., 2005. Remote control of behavior through genetically targeted photostimulation of neurons. Cell 121, 141-152.

LiU X., Ramirez S., PANG P. T., PURYear C. B., GOVINDARAJAN A., DEISSEROTH K., TONEGAWA S., 2012. Optogenetic stimulation of a hippocampal engram activates fear memory recall. Nature 484, 381-385

Madisen L., MaO T., Koch H., Zhuo J. M., BerENYI A., FuJisawa S., HSU Y. W., GaRCIA A. J. 3RD, Gu X., Zanella S., Kidney J., Gu H. MaO Y., Hooks B. M., BoYden E. S., BuZsákI 
G., Ramirez J. M., Jones A. R., SVOBOdA K., HAN X., TURNER E. E., ZENG H., 2012. A toolbox of Cre-dependent optogenetic transgenic mice for light-induced activation and silencing. Nat. Neurosci. 15, 793-802.

MATSUnO-YAGI A., MUKOHATA Y., 1977. Two possible roles of bacteriorhodopsin; a comparative study of strains of Halobacterium halobium differing in pigmentation. Biochem. Biophys. Res. Commun. 78, 237-243.

Nagel G., Ollig D., FuHRmann M., Kateriya S., Musti A. M., BAMBerg E., HegemanN P. 2002. Channelrhodopsin-1: a light-gated proton channel in green algae. Science 296, 2395-2398.

Nagel G., Szellas T., Huhn W., Kateriya S., Adeishvili N., BerThold P., Ollig D., HeGeMANN P., BAMBERG E., 2003. Channelrhodopsin-2, a directly light-gated cation-selective membrane channel. Proc. Natl. Acad. Sci. USA 100, 13940-13945.

NAGEL G., BRAUner M., Liewald J. F., AdEISHVILI N., BAMBERG E., GOTTSCHALK A., 2005. Light activation of channelrhodopsin-2 in excitable cells of Caenorhabditis elegans triggers rapid behavioral responses. Curr. Biol. 15, 22792284.

NARAHASHI T., MOORE J. W., SCOTT W. R., 1964. Tetrodotoxin blockage of sodium conductance increase in lobster giant axons. J. Gen. Physiol. 47, 965-974.

Oesterhelt D., Stoeckenius W., 1971. Rhodopsin-like protein from the purple membrane of Halobacterium halobium. Nat. New Biol. 233, 149-152.

OKUn M. S., 2012. Deep-brain stimulation for Parkinson's disease. N. Engl. J. Med. 367, 15291538.

PANEGYRES K. P., PANEGYRES P. K., 2016. The Ancient Greek discovery of the nervous system: Alcmaeon, Praxagoras and Herophilus. J. Clin. Neurosci. 29, 21-24.

PRAKASH R., YizhaR O., GREWE B., RAMAKRISHNAN C., Wang N., Goshen I., PACKer A. M., PeterKA D. S., Yuste R., Schnitzer M. J., DeISSEROTH K., 2012. Two-photon optogenetic toolbox for fast inhibition, excitation and bistable modulation. Nat. Methods. 9, 1171-1179.

Rickgauer J. P., DEISSERoth K., TANK D. W., 2014. Simultaneous cellular-resolution optical perturbation and imaging of place cell firing fields. Nat. Neurosci. 17, 1816-1824.

SAUER B., 1998. Inducible gene targeting in mice using the Cre/lox system. Methods 14, 381392.

Sparta D. R., Jennings J. H., Ung R. L., STUber G. D., 2013. Optogenetic strategies to investigate neural circuitry engaged by stress. Behav. Brain Res. 255, 19-25.

Sweeney S. T., Broadie K., Keane J., Niemann H., O'KANE C. J., 1995. Targeted expression of tetanus toxin light chain in Drosophila specifically eliminates synaptic transmission and causes behavioral defects. Neuron 14, 341351.

VASTOLA E. F., 1961. Anodal block of conduction in the optic tract. Am. J. Physiol. 200, 931935.

Wang H., Peca J., Matsuzaki M., Matsuzaki K., NOGUCHI J., QIU L., WANG D., ZHANG F., BOYDen E., Deisseroth K., Kasai H., Hall W. C., Feng G., Augustine G. J., 2007. High-speed mapping of synaptic connectivity using photostimulation in Channelrhodopsin-2 transgenic mice. Proc. Natl. Acad. Sci. USA 104, 81438148.

WilcoX M., ViOla R. ., Johnson K. W., BillingTON A. P., CARPENTER B. K., MCCRAY J. A., GuZIKOWSKI A. P., HESS G. P., 1990. Synthesis of photolabile "precursors" of amino acid neurotransmitters. J. Org. Chem. 55, 15851589.

YAMAMOTO M., WADA N., KitABATAKE Y., WATANABE D., AnZai M., YoKoYama M., Teranishi Y., NAKANISHI S., 2003. Reversible suppression of glutamatergic neurotransmission of cerebellar granule cells in vivo by genetically manipulated expression of tetanus neurotoxin light chain. J. Neurosci. 23, 6759-6767.

YASUDA R., Nimchinsky E. A., ScheUSS V., POLOGRUTO T. A., OERTNER T. G., SABATINI B. L., SvOBODA K., 2004. Imaging calcium concentration dynamics in small neuronal compartments. Sci. STKE 2004, pl5.

Zemelman B. V., Lee G. A., NG M., MiesenBöcK G., 2002. Selective photostimulation of genetically chARGed neurons. Neuron 33, 15-22.

Zemelman B. V., Nesnas N., LEe G. A., MieSenBOCK G., 2003. Photochemical gating of heterologous ion channels: remote control over genetically designated populations of neurons. Proc. Natl. Acad. Sci. USA 100, 1352-1357.

Zhang F., WANG L. P., BRAUNER M., LiEWALD J. F., KAY K., WATZKe N., WoOd P. G., BAMBERG E., Nagel G., GotTschalk A., Deisseroth K., 2007. Multimodal fast optical interrogation of neural circuitry. Nature 446, 633-639.

Zhang F., PRIGge M., Beyrière F., Tsunoda S. P., MatTis J., YizhaR O., Hegemann P., DEISSEROTH K., 2008. Red-shifted optogenetic excitation: a tool for fast neural control derived from Volvox carteri. Nat. Neurosci. 11, 631633.

Zhao S., Cunha C., Zhang F., LiU Q., Gloss B., Deisseroth K., Augustine G. J., FEnG G., 2008. Improved expression of halorhodopsin for light-induced silencing of neuronal activity. Brain Cell Biol. 36, 141-154. 
KOSMOS Vol. 69, 1, 59-80, 2020

DOMiniK KANIGOWSKI, JOANNA URBAN-CIEĆKO

Laboratory of Neurobiology, Nencki Institute of Experimental Biology PAS, 3 Pasteur Str., 02-093 Warszawa, E-mail: d.kanigowski@ nencki.edu.pl, j.ciecko@nencki.edu.pl

\section{OPTOGENETICS AND OTHER METHODS OF CONTROLLING THE NERVE CELLS ACTIVITY}

\section{Summary}

Controlling the electrical activity of selected and specific groups of nerve cells or even a single cell in the brain allows for understanding how neuronal networks process and code information. The ability to manipulate the activity of neurons is essential in studying the function and role of neuronal circuits in a healthy and diseased brain. Currently, there are many methods of nerve cells activity regulation based on various approaches and tools. These techniques differ greatly in cellular specificity, kinetics, and direction of action (activation/inhibition). In this article, we list various methods of nerve cells manipulation - since the 60's of the past century and ending with the latest techniques of the present time. We devote the most space to the description of opsins and the development of methods for the application of optogenetics. A separate chapter is devoted to the characteristics of the methods developed in recent years which use nanoparticles and optical manipulation of DNA transcription.

Key words: chemogenetics, nanoparticles, opsins, optogenetics 